\title{
DE LA CIUDAD CONVENTUAL A LA CIUDAD BURGUESA: LAS ÓRDENES RELIGIOSAS EN LA EVOLUCIÓN URBANA DE CÓRDOBA
}

\author{
POR \\ Yolanda Victoria Olmedo SÁNCHEZ \\ Universidad de Córdoba
}

\section{RESUMEN}

Este estudio se centra en el papel de los conventos y monasterios en el desarrollo urbano de Córdoba. Como instituciones espirituales y centros económicos y de poder, influyeron en la vida de sus habitantes, así como en la imagen y transformación de la ciudad. El dominio adquirido durante el Antiguo Régimen por estas fundaciones religiosas decayó con la consolidación de la burguesía. La desamortización alteró y destruyó en algunos casos antiguos conventos y monasterios. A lo largo del siglo XIX se creó una nueva ciudad, obra de una burguesía que modernizó su trazado urbano, dañando un rico patrimonio histórico y artístico.

PALABRAS ClAVE: Córdoba, fundaciones religiosas, conventos, monasterios, ciudad, transformaciones urbanas, desamortización, exclaustración.

\section{FROM CLOISTERED CITY TO THE BOURGEOIS CITY: RELIGIOUS ORDERS IN URBAN DEVELOPMENTS OF CORDOBA}

\begin{abstract}
This study focuses on the role of convents and monasteries in the urban development of Cordoba. As spiritual institutions and economic centers of power, influenced the lives of their inhabitants as well as in the image and transforming the city. The power acquired during the Ancien Regime by these religious foundations declined with the consolidation of the bourgeoisie. The confiscation altered
\end{abstract}


and destroyed in some cases former convents and monasteries. Throughout the nineteenth century created a new city, designed by a bourgeoisie which modernized its urban design, damaging a historic and artistic heritage.

KEY WORDS: Cordoba, religious foundations, convents, monasteries, city, urban transformations, disentitlement, secularization

Recibido/Received 2010-02-11

Aceptado/Accepted 2011-08-16

HACIA UNA CRISTIANIZACIÓN DE LA URBE: EL ESTABLECIMIENTO DE LAS PRIMERAS ÓRDENES RELIGIOSAS

La recuperación cristiana de Córdoba en 1236 marcó el inicio de una nueva etapa histórica, que iría acompañada de una paulatina transformación en su morfología urbana. El establecimiento de los primeros templos parroquiales constituyó una importante medida, encaminada a la cristianización de una población hasta entonces de dominio islámico. Centros neurálgicos de las collaciones en las que se dividió la ciudad, tales iglesias se ubicaron en el interior del recinto murado, ocupando los dos ámbitos en los que se dividía la antigua urbe musulmana: al-Madina al-Atica y al-Madina al-Sharqiyya; zonas que en época cristiana pasarían a ser conocidas, respectivamente, por la Villa y la Ajerquía. ${ }^{1}$ Ambos sectores serían urbanizados durante los últimos siglos medievales, especialmente la Ajerquía o zona oriental de la ciudad, que disponía de amplios espacios vacíos. ${ }^{2}$ Junto a los templos parroquiales, las fundaciones cenobiales ejercieron una importante labor en la cristianización de la Córdoba bajomedieval. Numerosas fueron las órdenes religiosas que se asentaron en la ciudad, contando algunas con el favor de la realeza.

Entre 1240 y 1241 fue fundado el Monasterio de San Pablo, de frailes predicadores, en la zona meridional de la collación de San Andrés, en unos terrenos concedidos por el monarca para tal fin. El rey Santo colocaría la primera piedra del cenobio, dedicándolo a San Pablo por haber reconquistado Córdoba el día de su festividad. Próximos a los dominicos surgía por estas mismas fechas, en la vecina collación de San Nicolás de la Ajerquía, el Monasterio de San Pedro el Real de franciscanos. Ambos cenobios quedaron emplazados en unos entornos despoblados, frente a la muralla que separaba esta zona oriental de la ciudad,

\footnotetext{
${ }^{1}$ Encabezadas por sus respectivos templos parroquiales, las collaciones fueron las siguientes: San Nicolás, San Pedro, San Andrés, Santa Marina, San Lorenzo y Santa María Magdalena, en la zona de la Ajerquía. Santa María (advocación que recibió la antigua Mezquita Aljama), San Juan, Omnium Sanctorum, San Nicolás, San Miguel, San Salvador y Santo Domingo, en la zona de la Villa. En el siglo XIV surgiría en esta zona occidental de la ciudad una nueva collación, bajo la advocación de San Bartolomé.

${ }^{2}$ Cfr. Escobar Camacho, J. M. 1989. Córdoba en la Baja Edad Media. (Evolución urbana de la ciudad): 73-83. Córdoba: Caja Provincial de Ahorros de Córdoba.
}

Hispania Sacra, LXIV

129, enero-junio 2012, 29-66, ISSN: 0018-215-X, doi: 10.3989/hs.2012.002 
de la Villa o zona occidental. Muy bien acogidos por la sociedad cordobesa, los alrededores de sendos monasterios irían poblándose durante las dos siguientes centurias.

La urbanización de los alrededores de San Pablo sería favorecida por los propios dominicos, con la intención de obtener dinero para la fabricación de su templo. De este modo, erigieron edificios en la huerta y en el corral del monasterio, con el fin de arrendarlos o venderlos a particulares; asimismo, cedieron solares dentro del propio cenobio para su posterior edificación. La iglesia conventual, único edificio conservado, constituye un interesante ejemplo de la arquitectura medieval cristiana en Córdoba.

Significativa sería también la urbanización del entorno de los franciscanos, convertido desde entonces en un importante enclave comercial. A lo largo de los siglos XIII y XIV, la comunidad de San Pedro el Real ampliaría su solar gracias a las donaciones de particulares, edificando su templo a mediados de esta última centuria. En el transcurso de la época moderna volverían a efectuarse obras en el monasterio, siendo posteriormente muy dañado.

El rey Santo fundaría igualmente, en 1241, el Monasterio de la Santísima Trinidad, de trinitarios calzados. El cenobio quedó ubicado en el extremo más occidental de la Villa, en un gran espacio de la collación de Omnium Sanctorum. Al igual que los dominicos y franciscanos, los trinitarios gozaron durante la etapa bajomedieval de gran consideración entre la población cordobesa. El conjunto trinitario iría transformándose con el paso de los siglos. De hecho, el templo originario sería sustituido por el actual, tratándose de un edificio barroco construido entre la segunda mitad del siglo XVII y principios del XVIII. ${ }^{3}$

\footnotetext{
${ }^{3}$ Sobre estos tres conventos véanse: Ramírez de Arellano y Gutiérrez, T. 1998. Paseos por Córdoba, o sean Apuntes para su Historia. (Prólogo de M. Salcedo Hierro): 155-173 y 289-295. Córdoba: Librería Luque. León: Everest. (Octava edición). Ramírez y de las Casas-Deza, L. M. 1976. Indicador cordobés. Manual histórico topográfico de la ciudad de Córdoba: 179-187. León: Everest. (Edición realizada partiendo de la cuarta edición hecha en Córdoba en 1867). Escobar Camacho, J. M. 1985. La vida urbana cordobesa: El Potro y su entorno en la Baja Edad Media: 87-94. Córdoba: Caja Provincial de Ahorros de Córdoba, Obra Cultural. Escobar Camacho, J. M. 1989: 155-156, 193, 195-196 y $224-$ 229. Sobre el antiguo cenobio de la Trinidad véase el estudio de Porres Alonso, B. 2007. La Trinidad de Córdoba. Convento y parroquia (1236-1998). Córdoba: Secretariado Trinitario. La historia y la arquitectura del monasterio franciscano ha sido estudiada, especialmente, por Castellano Cuesta, M. T. 1988. La Iglesia de San Francisco y San Eulogio de la Ajerquía de Córdoba. Córdoba: Monte de Piedad y Caja de Ahorros de Córdoba. Sobre el convento de San Pablo véase Serrano Ovín, V. 1975. «La iglesia del Real Convento de San Pablo. Córdoba». Boletín de la Real Academia de Córdoba 95: 76-130. Respecto a las edificaciones medievales de los dominicos y franciscanos, véanse los siguientes estudios: Jordano Barbudo, M. A. 1996. Arquitectura medieval cristiana en Córdoba (desde la reconquista al inicio del Renacimiento): 42-71 y 116-124. Córdoba: Universidad de Córdoba, Servicio de Publicaciones. Jordano Barbudo, M. A. 2002. El Mudéjar en Córdoba: 43-48, 51, 55, 58-59, 61 y 63. Córdoba: Diputación Provincial de Córdoba.
} 
Otras comunidades masculinas establecidas en Córdoba, poco después de la reconquista, fueron los agustinos y los mercedarios calzados: ${ }^{4}$

El Monasterio de San Agustín tuvo diversos emplazamientos antes de establecerse definitivamente en la collación de Santa Marina. Fundado por Fernando III, primero estuvo ubicado fuera del recinto murado, al otro lado del río, en el llamado Campo de San Julián (actual Campo de la Verdad). Sin embargo, pronto abandonaría este lugar por el peligro provocado por las frecuentes incursiones de los moros de Granada. En 1313 sería trasladado al interior de la ciudad, concretamente a la collación de San Bartolomé, estableciéndose en el espacio que poco después pasaría a ocupar el Alcázar de los Reyes Cristianos. La comunidad agustina permanecería aquí poco tiempo, trasladándose en 1328 a la collación de Santa Marina donde ocuparon unas casas y huerta, donadas para tal fin por el rey Alfonso XI el Justiciero. En lo sucesivo, los religiosos procederían a la construcción del monasterio que llegaría a adquirir una gran extensión, convirtiéndose en un importante núcleo de repoblación. En el siglo XVII el cenobio sería muy transformado, desapareciendo posteriormente las dependencias conventuales con la exclaustración. De ahí que los únicos restos medievales conservados sean la cabecera, el crucero y los muros de la iglesia.

El Convento de Ntra. Sra. de la Merced, de mercedarios calzados, fue fundado hacia 1250 a extramuros, en el ámbito septentrional de la ciudad, frente a la llamada Puerta de Osario. En dicho enclave Fernando III donó a los frailes un amplio espacio, así como una pequeña ermita consagrada a Santa Eulalia. A lo largo de las siguientes centurias bajomedievales el entorno del cenobio iría poblándose, dando lugar a la aparición de diversos barrios de carácter industrial dedicados, especialmente, a la fabricación de objetos de barro y de adobes para la construcción. El edificio conventual sería sometido a profundas transformaciones durante el siglo XVIII y tras la exclaustración.

Al referirnos a los cenobios cordobeses, hemos de aludir también al Monasterio de San Hipólito. Fundado en 1343 por Alfonso XI en la collación de San Nicolás de la Villa, cuatro años después pasaría a convertirse en colegiata, destinada a panteón real y a la celebración de cultos en memoria de los reyes difuntos. Posiblemente, Alfonso XI tuvo la intención de que una comunidad regular se hiciera cargo del templo, antes de constituirse en colegiata. Sin embargo, tan sólo se tiene constancia de la presencia de un prior y un sacristán al servicio del mismo. ${ }^{5}$

${ }^{4}$ Vid. Escobar Camacho, J. M. 1989: 116-117, 119 y 242. Ramírez de Arellano y Gutiérrez, T. 1998: 101-105 y 358-371. Ramírez de Arellano y Díaz de Morales, R. 1983. Inventario monumental y artístico de la provincia de Córdoba. (Con notas de J. Valverde Madrid): 177-178. Córdoba: Monte de Piedad y Caja de Ahorros de Córdoba. Ramírez y de las Casas Deza, L. M. 1976: 187-191. Respecto a la arquitectura de San Agustín, véase Jordano Barbudo, M. A. 1996: 137-142.

${ }^{5}$ Vid. Vázquez Lesmes, J. R. 1978. «Monasterio y colegiata de San Hipólito de Córdoba (13431399)», en Andalucía Medieval. Actas I Congreso de Historia de Andalucía, Vol. 2: 147-161. Córdoba: 
En cuanto a las comunidades femeninas, las primeras religiosas en establecerse en Córdoba fueron las de Santa Clara. La fundación de este cenobio corrió a cargo del arcediano de la Catedral de Córdoba, don Miguel Díaz, quien, hacia 1263, compró con tal intención una casa en la collación de Santa María. El inmueble, ubicado en la calle Francos, lindaba con unas casas propiedad del infante don Luis, hijo de Fernando III. Dos años después, Alfonso X autorizaba a su hermano la venta de dichas casas (que habían pertenecido a la madre de ambos, la reina doña Juana de Ponthieu), con el fin de incluirlas en la clausura. La ampliación del espacio conventual no tardaría en efectuarse. Próxima al monasterio existía una pequeña mezquita, construida a fines del siglo $\mathrm{X}$ o principios del XI, en el solar en donde existió un templo paleocristiano de la segunda mitad del siglo VI. En 1244 había sido donada por Juan de Funes, alguacil mayor de Córdoba, al obispo Lope de Fitero y al Cabildo Catedralicio. Posteriormente, el rey Santo la consagraría al culto cristiano con el nombre de Santa Catalina, quedando incluida en la clausura en 1267.

En lo sucesivo, las religiosas irían ensanchando sus dependencias con la adquisición de casas aledañas, hasta llegar a ocupar una gran manzana comprendida entre las actuales calles Rey Heredia, Osio y Portería de Santa Clara. El recinto conventual sufriría algunas transformaciones, con el fin de adaptarse a las necesidades impuestas por la vida de oración. Entre finales del siglo XIV y primer tercio del $\mathrm{XV}$, se alzaría un nuevo templo sobre el patio de abluciones de la antigua mezquita, aprovechándose algunos elementos musulmanes como el alminar. De este modo, el antiguo oratorio quedó convertido en coro. En el transcurso de la época moderna volverían a efectuarse obras en el cenobio. ${ }^{6}$

Alfonso X sería el fundador, hacia 1260, del Monasterio de San Clemente de monjas cistercienses. Aunque se desconoce la fecha en que fue erigido, hay constancia de que el monarca concedió ciertos privilegios a la comunidad, entre ellos unas huertas para su edificación. Las investigaciones más recientes apuntan a que este claustro femenino estuvo ubicado en la Ajerquía, en una zona próxima a la Villa, concretamente, en el límite de la collación de San Andrés con la de San Salvador. No obstante, la estancia en Córdoba de esta comunidad cisterciense sería breve. En fecha posterior a 1277 se trasladaría al Monasterio de San Clemente de Sevilla, decisión tal vez del propio Alfonso X como con-

Monte de Piedad y Caja de Ahorros de Córdoba. Sobre la arquitectura de esta fundación véase Jordano Barbudo, M. A. 1996: 143-149.

${ }^{6}$ Cfr. Escribano Castilla, A. 1982. «Fundaciones franciscanas en la Córdoba bajomedieval», en Andalucía Medieval. Actas I Coloquio Historia de Andalucía: 332-333 y 347. Córdoba: Monte de Piedad y Caja de Ahorros de Córdoba. Sobre la arquitectura de este monasterio, remitimos a dos estudios ya citados: Jordano Barbudo, M. A. 1996: 14-20. Jordano Barbudo, M. A. 2002: 97-100. Respecto al primitivo templo paleocristiano que existió en el solar de la mezquita donada al convento, véase Marfil Ruiz, P. 1996. «La iglesia paleocristiana de Santa Catalina en el Convento de Santa Clara de Córdoba». Caetaria 1: 33-43. 
secuencia del conflicto bélico, que le llevó a enfrentarse con su hijo el infante don Sancho.

Tras el traslado de la comunidad de San Clemente a Sevilla, el único cenobio femenino existente en Córdoba, durante casi una centuria, sería el Monasterio de Santa Clara. Habrá que esperar hasta 1372, para asistir a la fundación del Monasterio de Santa María de las Dueñas. Esta clausura cisterciense tendría, en cambio, una larga permanencia en la ciudad. Su fundador fue don Enrique Venegas, alcalde mayor de Córdoba y primer señor de Luque, quien hallándose en peligro en 1364 (defendiendo a Pedro I de Castilla en el conflicto bélico que lo enfrentó a Pedro IV de Aragón), prometió erigir un cenobio. Junto a su esposa, doña Beatriz de Tolosán, donaría la casa que ambos poseían en la collación de San Salvador para fundar un claustro femenino, eligiéndose la Orden del Cister tal vez por devoción familiar. Ante el incremento de la comunidad, durante el siglo XV se efectuaron reformas y ampliaciones dentro del monasterio. De este modo, llegó a ocupar una vasta extensión, disponiendo incluso de un paso subterráneo que, atravesando la calle del Cister y algunas casas, desembocaba en un mirador ubicado a la salida de la Cuesta del Bailío.

Otro cenobio femenino cisterciense fue el Monasterio de la Purísima Concepción de Ntra. Sra., si bien, en un principio, no se dispuso que fuese regido por dicha Orden. Su fundación se debió a doña Beatriz de los Ríos, perteneciente a una importante familia de la nobleza vinculada al poder de la ciudad. Su padre, don Alonso de los Ríos, era miembro del Cabildo Municipal; su madre, doña Inés Alfonso de Montemayor, era señora de Fernán Núñez. Doña Beatriz empleó la herencia materna en la fundación de un beaterio. Posteriormente, en su testamento otorgado en 1487, ordenó que en las casas de su morada (situadas en las proximidades del templo parroquial de San Nicolás de la Villa), se erigiera un monasterio femenino que habría de recibir, principalmente, a las doncellas y dueñas de su linaje. El cenobio debería regirse por la Regla de Santo Domingo y estar bajo la obediencia de los prelados de esta Orden. No obstante, en la bula fundacional, otorgada por Julio II en 1506, se ordenó la fundación de un monasterio bajo la Regla de San Benito y San Bernardo. La intervención de don Tomás de Córdoba, último abad del Monasterio de los Santos Mártires, en la toma de posesión de los bienes muebles de doña Beatriz de los Ríos, puede justificar el hecho de que estas religiosas se sometiesen a la Orden del Cister. El acondicionamiento para la clausura de las casas de la fundadora se efectuaría a lo largo del siglo XVI.

Frente a las numerosas comunidades femeninas cistercienses que se establecieron en Córdoba desde la etapa bajomedieval, el Convento de los Santos Mártires fue la única casa masculina de dicha Orden que existió en la ciudad. La vida de esta comunidad sería breve, llegando tan sólo hasta los primeros años del Quinientos, coincidiendo su desaparición con el nacimiento del citado Mo- 
nasterio de la Concepción. El Convento de los Mártires fue fundado durante la primera mitad del siglo XIV a extramuros, en el extremo sureste de la collación de Santiago. En este lugar existía un templo dedicado a San Acisclo y Santa Victoria, mártires del siglo IV sepultados -según la tradición- en dicho enclave. En 1332 el obispo don Gutierre Ruiz de Mesa y el Cabildo cedieron el templo a frey Alonso Ruiz, monje cisterciense que lo había solicitado para su Orden. A lo largo de casi dos centurias, esta comunidad protagonizaría una estrecha relación con la sociedad cordobesa. ${ }^{7}$

Durante el siglo XV se intensifica el proceso de sacralización urbana, tras las escasas fundaciones cenobiales de la centuria anterior. No obstante, la mayoría de los claustros masculinos fundados en el Cuatrocientos optaron por la búsqueda de un retiro espiritual apartado de la ciudad, asentándose en la sierra cordobesa. Tal es el caso del Monasterio de San Jerónimo de Valparaíso, del Convento de San Francisco de la Arruzafa y del Convento de Santo Domingo de Scalacoeli. Asimismo, hemos de citar el Convento de Ntra. Sra. de los Remedios y San Rafael, también llamado Convento Madre de Dios. Perteneciente a la Orden Tercera de San Francisco, fue fundado a extramuros, en unos terrenos situados en el sector oriental de la ciudad. No obstante, a principios del siglo XVI sería trasladado a un enclave de la collación de Santiago. ${ }^{8}$

Como en otras urbes peninsulares, en la Córdoba bajomedieval fue habitual el establecimiento de religiosas en las casas de los fundadores. Asimismo, hubo cenobios que tuvieron su origen en beaterios, grupos espontáneos de mujeres consagradas a la vida de oración. Tal es el caso de algunos claustros fundados en el último tercio del siglo XV.

Siguiendo un criterio cronológico, hemos de referirnos en primer lugar al Convento de Santa Inés, de religiosas franciscanas. Su fundación en 1471 se debió a doña Leonor Fernández de Mesa, viuda del caballero cordobés don Alfonso Fernández de Mesa. La clausura quedó ubicada en unas casas de la collación de la Magdalena, donadas anteriormente por Juan Ruiz a unas beatas. La

\footnotetext{
${ }^{7}$ Cfr. Ramírez de Arellano y Gutiérrez, T. 1998: 241-246 y 413. Ramírez y de las Casas-Deza, L. M. 1976: 191-194, 210-211 y 216. Escobar Camacho, J. M. 1989: 175, 177 y 272. Nieto Cumplido, M., Padilla González, J. y Escobar Camacho, J. M. 1984. «Vida y presencia de la mujer en la Córdoba del siglo XIII», en C. Segura Graíño (ed.), Las mujeres en las ciudades medievales. Actas de las Terceras Jornadas de Investigación Interdisciplinaria: 139-140. Madrid: Universidad Autónoma de Madrid, Servicio de Publicaciones. Sobre estas fundaciones cistercienses en la Córdoba bajomedieval véase, especialmente, Cerrato Mateos, F. 2006. El Cister de Córdoba. Historia de una clausura: 33-52. Córdoba: Universidad de Córdoba. La arquitectura de estos cenobios ha sido estudiada por Jordano Barbudo, M. A. 2002: 180-186.

${ }^{8}$ Vid. Ramírez de Arellano y Gutiérrez, T. 1998: 247-248, 523-527 y 528-533. Escribano Castilla, A. 1982: 342-343. Sobre algunos de estos cenobios, véanse también: Gutiérrez de los Ríos y ParejaObregón, M. 1909. Fundaciones monásticas en la Sierra de Córdoba. Córdoba: Diario Córdoba. Gracia Boix, R. 1973. El Real Monasterio de San Jerónimo de Valparaíso en Córdoba. Córdoba: Real Academia de Córdoba de Ciencias, Bellas Letras y Nobles Artes.
} 
estrechez del inmueble y la escasez de rentas para mantenerse, obligaron a la comunidad a trasladarse en 1474 al recién fundado cenobio de Santa Cruz, de religiosas clarisas. Esto no supuso la definitiva desaparición de Santa Inés, pues ese mismo año el pontífice Sixto IV autorizaba nuevamente la fundación del convento, trasladándose al mismo dos monjas del Monasterio de Santa Clara.

Las religiosas de Santa Inés fueron, pues, las primeras moradoras del Convento de Santa Cruz, fundado en 1474 por doña Teresa Zurita siguiendo el deseo de su difunto esposo, don Pedro de los Ríos. Esta clausura quedó ubicada en las casas principales de este caballero cordobés, situadas en el extremo oriental de la collación de San Pedro, en el límite con la de Santiago. En los últimos años del siglo XV, quedaría fraguada la estructura general del cenobio con la construcción de la iglesia y la inclusión en la clausura de casas lindantes. A este respecto, en 1489 sería ampliado con una casa adyacente en la que había sido fundado otro convento de religiosas franciscanas, que terminaría mudando su emplazamiento a la collación de Santa Marina. Posteriormente, en el transcurso de las centurias modernas, todo este conjunto sería objeto de una gran ampliación. A la etapa medieval corresponde la configuración espacial del templo, el claustro grande, algunos elementos del patio de entrada, así como algunos alfarjes mudéjares.

Tal y como acabamos de indicar, en la collación de San Pedro, junto al Convento de Santa Cruz, se halla el origen de otro cenobio de franciscanas. En 1485 doña Marina de Villaseca (hija de don Alonso Fernández de Villaseca y viuda de don García de Montemayor), pedía permiso a Sixto IV para fundar un claustro de Hermanas de la Tercera Orden de San Francisco, en una casa que poseía en la calle de Valderrama. Cuatro años más tarde la fundadora solicitaba un cambio de residencia de la comunidad, ante las reducidas dimensiones del inmueble, alegando también que éste había sido requerido por las religiosas del vecino Convento de Santa Cruz para su ampliación. En 1491 Inocencio VIII autorizaba el traslado del cenobio, quedando establecido definitivamente en la collación de Santa Marina, frente a la iglesia parroquial. En este nuevo enclave las religiosas se asentaron en unas casas adquiridas por doña Marina de Villaseca, situadas junto a una ermita consagrada a la Visitación de la Virgen a Santa Isabel. Tal advocación justifica el hecho de que, a partir de entonces, este convento adoptase el nombre de Santa Isabel de los Ángeles.

Durante la última década de la centuria se efectuaron obras en el cenobio, ante el incremento de religiosas. En 1493 el chantre de Córdoba y el juez de términos recibían una comisión de doña María de Pedrosa, viuda de don Juan de Armenta, ya que ambos la obligaban a vender una parte de su huerta para añadirla a las dependencias monjiles, que se hallaban entonces en obras. Éstas proseguirían al año siguiente, fecha en la que fue preciso desalojar dos casas existentes junto al convento, pertenecientes a don Juan y a don Diego de Pedrosa. Tales inmuebles 
fueron vendidos a doña Marina de Villaseca por el licenciado Montiel, según lo dispuesto en una real provisión firmada por los Reyes Católicos. Siendo objeto de una profunda transformación durante la época moderna, el Convento de Santa Isabel de los Ángeles tan sólo ha conservado de la etapa medieval parte del templo, así como algunos capiteles mudéjares reutilizados en el claustro. ${ }^{9}$

No muy lejos del anterior había surgido, unos años antes, el Monasterio de Santa Marta, de monjas jerónimas. El origen de este claustro se encuentra en un beaterio establecido en 1454 en una casa señorial de la collación de San Andrés, conocida por el Corral de Cárdenas. Allí vivían varias señoras junto a la propietaria, doña Catalina López de Morales -viuda de don Juan Pérez de Cárdenas-, quien en 1455 donaría el inmueble a sus compañeras. Fueron éstas las que iniciaron los trámites para convertir el beaterio en cenobio, hecho finalmente aprobado en 1464 por Paulo II. Dos años después las religiosas incorporaban a la clausura la aledaña Casa del Agua, propiedad de doña María Carrillo, viuda de don Lope Angulo. El proceso concluiría en 1468, fecha en la que el obispo de Córdoba, don Pedro de Solier, aprobaba la fundación del Monasterio de Santa Marta. A ello se opusieron los dominicos de San Pablo, dada la proximidad entre ambos cenobios. Tal conflicto daría lugar en 1470 a un pleito, cuya sentencia resultó favorable a las religiosas.

Este monasterio de jerónimas llegó a ocupar una vasta extensión, disponiendo de dos claustros, varios patios y un huerto para su autoabastecimiento. La planta del mismo respondía a un esquema laberíntico, característica igualmente presente en otras clausuras femeninas de la Córdoba del siglo XV. El huerto y algunas estancias se situaban al otro lado del callejón de Santa Marta, comunicándose con el resto de la clausura a través de un túnel que discurría por debajo de esta estrecha vía. Al parecer, en dicho enclave se hallaba el Corral de Cárdenas, inmueble en donde primeramente estuvo ubicado el beaterio.

Las dependencias de las religiosas resultan de gran interés, tratándose de un buen ejemplo de arquitectura doméstica bajomedieval de clara influencia musulmana. Las muestras de arte mudéjar son claramente visibles en el llamado claustro del cinamomo (originariamente, patio principal de la Casa del Agua), así como en las estancias situadas a su alrededor. La construcción de este inmueble debió iniciarse a principios del siglo XV, efectuándose algunas reformas, así como la edificación del segundo piso, entre finales de esta centuria y la primera mitad del XVI. El templo, en cambio, responde al tránsito entre el último Gótico

\footnotetext{
${ }^{9}$ Sobre estos conventos franciscanos confróntense: Ramírez de Arellano y Gutiérrez, T. 1998: 31 32, 96-97 y 206-207. Escribano Castilla, A.1982: 343-345. Escobar Camacho, J. M. 1989: 210-211, 242-243 y 264-265. Véase también el estudio de Herrera Mesa, P. P. 2004. «El Real Convento de Santa Inés de Córdoba: fundación, patrimonio y desaparición», en F. J. Campos y Fdez. de Sevilla (dir.), $L a$ clausura femenina en España. Actas del Simposium II: 911-938. San Lorenzo del Escorial (Madrid): R.C.U. Escorial-M ${ }^{\mathrm{a}}$ Cristina, Servicio de Publicaciones. Sobre la arquitectura de dichos cenobios: Jordano Barbudo, M. A. 1996: 14-20 y 228-234. Jordano Barbudo, M. A. 2002: 186-190.
} 
y el primer Renacimiento. Iniciado a finales del siglo XV por Gonzalo Rodríguez, las obras fueron continuadas por su hijo Hernán Ruiz I en los primeros años del Quinientos. ${ }^{10}$

Finalmente, hemos de referirnos a dos cenobios femeninos de la orden de Santo Domingo: el Convento de Santa María de Gracia y el Convento de Regina Coeli. Los orígenes del primero se remontan a 1475, fecha en la que don Pedro Ruiz de Cárdenas, alcalde mayor y veinticuatro de Córdoba, dejaba indicado en su testamento que sus casas principales, situadas en la collación de San Lorenzo (en la calle que iba desde la iglesia parroquial hasta el Realejo de San Andrés), se destinasen a la fundación de este claustro de religiosas, dejando para su mantenimiento diversos bienes. Tratándose de un cenobio de mediana extensión, su templo fue construido a principios del siglo XVII. El Convento de Regina Coeli sería fundado en 1499 en la collación de San Pedro, en unas casas pertenecientes a doña Mencía de los Ríos, ubicadas en una plaza a la que terminaría dando nombre. Este cenobio, que llegó a disponer de una gran extensión, muestra hoy un desolador aspecto. Se conservan algunos restos de la clausura, así como el templo. Erigido este último durante la segunda mitad del XVI, presenta al exterior sencilla portada con arco carpanel. ${ }^{11}$

Este recorrido por las fundaciones regulares de la Córdoba bajomedieval (véanse Cuadros 1 y 2), nos permite deducir lo siguiente:

Los cenobios masculinos, más numerosos que los femeninos, se establecieron tanto a intramuros como a extramuros, así como en lugares apartados de la ciudad, Siendo en su mayoría impulsados por la realeza, estuvieron dotados de amplios espacios para erigir sus dependencias, por lo que fueron adaptados, desde un principio, a la vida de los religiosos. Por el contrario, los cenobios femeninos se ubicaron todos a intramuros y salvo una excepción -el Monasterio de Santa Clara-, surgieron gracias a las iniciativas de miembros de destacadas familias, que cedieron casas de su propiedad para tal fin. Se explica así el carácter doméstico de muchos claustros de religiosas, que debieron ir adaptándose a su nueva función; precisando de sucesivas transformaciones y ampliaciones, para preservar la clausura y alojar un número creciente de monjas.

\footnotetext{
${ }^{10}$ Vid. Orti Belmonte, M. A.1989. «El Convento de Santa Marta», Vida y Comercio 48: s.p. Escobar Camacho, J. M. 1989: 229-230. Sobre la arquitectura de este cenobio: Jordano Barbudo, M. A. 1996: 213-220. Jordano Barbudo, M. A. 2002: 148-164. Jordano Barbudo, M. A. 1999. «Conventos de jerónimas en antiguos palacios mudéjares: el ejemplo de Santa Marta en Córdoba», en F. J. Campos y Fdez. de Sevilla (dir.), La Orden de San Jerónimo y sus Monasterios. Espiritualidad, historia, arte, economía y cultura de una Orden religiosa ibérica. Actas del Simposium I: 359-379. San Lorenzo del Escorial (Madrid): R.C.U. Escorial-M ${ }^{\mathrm{a}}$ Cristina, Servicio de Publicaciones.

${ }^{11}$ Vid. Ramírez de Arellano y Gutiérrez, T. 1998: 59-60 y 200-201. Ramírez y de las Casas-Deza, L. M. 1976: 212-213. Escobar Camacho, J. M. 1989: 211 y 253-254. Jordano Barbudo, M. A. 1996: 205-207. Jordano Barbudo, M. A. 2002: 191-192.
}

Hispania Sacra, LXIV

129, enero-junio 2012, 29-66, ISSN: 0018-215-X, doi: 10.3989/hs.2012.002 
Las fundaciones monásticas y conventuales realizadas a intramuros contribuyeron a la configuración de algunos ámbitos de la ciudad. Tal es el caso de la Ajerquía, que fue urbanizándose en el transcurso de la etapa bajomedieval. Dotada de amplios espacios, muchos de ellos fueron ocupados por órdenes religiosas, justificándose así la mayor concentración cenobial producida en esta zona oriental de la capital cordobesa.

El panorama conventual descrito constituye la base sobre la cual irá forjándose la Córdoba Moderna. Tal y como comentaremos a continuación, a partir del Quinientos la ciudad seguirá recibiendo la llegada de nuevas comunidades religiosas, que contribuirán a consolidar el carácter sagrado de su espacio.

\section{LA CONSOLIDACIÓN DE LA CÓRDOBA CONVENTUAL}

Al igual que otras ciudades hispanas, la Córdoba del Quinientos quedó marcada por el esplendor económico y por el espíritu contrarreformista de la época. Ambos factores incidieron en su imagen, mejorando y sacralizando muchos de sus espacios. En el transcurso de esta centuria el Concejo Municipal emprendió diversas actuaciones, destinadas a embellecer la ciudad y a dotarla de un cariz más acorde con los nuevos tiempos. Sin embargo, tales intervenciones no llegaron a borrar la huella medieval de su tejido urbano, dominado por calles estrechas y tortuosas heredadas de su pasado musulmán. ${ }^{12}$

Durante el Renacimiento el urbanismo cordobés mostró, pues, un aspecto híbrido al mezclarse lo viejo con lo nuevo; la trama medieval con vías rectas y espacios regularizados, surgidos en algunos enclaves de la capital. Tal dualidad siguió estando presente hasta el siglo XIX, período en el que se emprenden grandes remodelaciones en la ciudad.

Formando parte del urbanismo, la arquitectura fue también objeto de transformaciones en pro de los nuevos aires renacentistas, contribuyendo igualmente a renovar la faz de la urbe cordobesa. El nuevo arte se materializó en algunos edificios heredados del medievo y muy especialmente en la MezquitaCatedral, que fue adoptando un semblante más acorde con su función de templo mayor. Las obras realizadas a lo largo de las centurias modernas otorgaron al conjunto catedralicio un aspecto más cristianizado. Así se aprecia en su

${ }^{12}$ Sobre el urbanismo de la Córdoba del siglo XVI véanse: Escobar Camacho, J. M. 1999. «La ciudad de Córdoba a fines del siglo XVI: su evolución urbana», en R. Vázquez Lesmes y M. Ventura Gracia (coords.), Córdoba en tiempos de Felipe II. Actas de las Jornadas de la Real Academia de Córdoba: 173-185. Córdoba: Caja de Ahorros y Monte de Piedad de Córdoba, Obra Social y Cultural. Y, especialmente, el estudio de Puchol Caballero, M. D. 1992. Urbanismo del Renacimiento en la ciudad de Córdoba. Córdoba: Diputación Provincial de Córdoba. 
nueva torre campanario, convertida desde entonces en un hito del paisaje de la ciudad. ${ }^{13}$

La prosperidad del Quinientos se manifestó también en templos parroquiales y conjuntos cenobiales. Los monasterios y conventos fueron piezas indiscutibles de las poblaciones, incidiendo en la trayectoria de las mismas durante las centurias modernas. Siendo instituciones de vida religiosa se convirtieron también en centros de poder, dotados de una gran capacidad de influencia en la vida local.${ }^{14}$ Córdoba constituye un buen ejemplo de aquella España conventual que fue fraguándose desde el siglo XVI. De hecho, en el transcurso de esta centuria se asientan en la ciudad numerosas órdenes religiosas. Impulsadas por la religiosidad surgida de Trento, contribuyeron a la construcción, así como a la sacralización de la misma. Es así cómo, poco a poco, la capital cordobesa fue adquiriendo la imagen de ciudad-convento. Las nuevas comunidades masculinas quedaron ubicadas en muy distintos emplazamientos, tanto dentro como fuera del recinto murado. El establecimiento de conventos extramuros supuso la creación de puntos de atracción poblacional, y los caminos que conducían hasta ellos y a otros núcleos, sirvieron de nexos de unión. ${ }^{15}$ Por su parte, todas las fundaciones femeninas del siglo XVI se efectuaron dentro del recinto murado, optando preferentemente por los barrios más importantes, tanto desde el punto de vista social como económico. ${ }^{16}$

Durante el siglo XVII proseguirían las fundaciones pese a la dificultosa situación económica, justificándose así la oposición a la llegada de nuevas comunidades, hecho que afectó especialmente a las masculinas. Pese a ello, en el transcurso de esta centuria abrirían casa los trinitarios descalzos, los capuchinos y los franciscanos alcantarinos, siguiendo los pasos de las comunidades que ya

\footnotetext{
${ }^{13} \mathrm{Tal}$ es la imagen que ofrece en las numerosas vistas de Córdoba, realizadas a partir del Quinientos, en las que destaca el marcado protagonismo del campanario catedralicio. Iniciado por Hernán Ruiz III en la última década del siglo XVI, las obras del mismo se completarían durante la siguiente centuria, siendo objeto de algunas transformaciones en el Setecientos. Convertido en un emblema de la ciudad, el campanario se halla representado en el escudo de la Catedral y en el escudo del Ayuntamiento cordobés. Sobre este tema véase Cosano Moyano, F. 1999. Iconografía de Córdoba. Siglos XIII-XIX. Catalogación de imágenes urbanas, heráldicas, hagiográficas y de poblaciones del antiguo reino de Córdoba: 25-91, 198-223, 241-244 y 292-304. Córdoba: Caja de Ahorros y Monte de Piedad de Córdoba, Obra Social y Cultural.

${ }^{14}$ Sobre este tema véase el interesante estudio de Atienza López, A. 2008. Tiempos de conventos. Una historia social de las fundaciones en la España Moderna. Madrid: Marcial Pons. Logroño: Universidad de Logroño.

${ }^{15}$ Rodríguez Marín, F. J. 2000. Málaga Conventual. Estudio Histórico, Artístico y Urbanístico de los Conventos Malagueños: 29. Málaga: CajaSur, Obra Social y Cultural. Arguval.

${ }^{16}$ Cfr. Gómez Navarro, S. 2005. «Por esos caminos de Dios: Asentamiento y expansión del monacato femenino en la Córdoba Moderna», en M. I. Viforcos Marinas y M. D. Campos Sánchez (coords.), Fundadores, fundaciones y espacios de vida conventual. Nuevas aportaciones al monacato femenino. III Congreso Internacional sobre el Monacato Femenino en España, Portugal y América: 198-199. León: Universidad de León.
}

Hispania Sacra, LXIV

129, enero-junio 2012, 29-66, ISSN: 0018-215-X, doi: 10.3989/hs.2012.002 
lo hicieron a lo largo del Quinientos: los mínimos de San Francisco de Paula, los carmelitas calzados y descalzos, los jesuitas, la orden hospitalaria de San Juan de Dios y los basilios.

Uno de los primeros cenobios fundados en el siglo XVI fue el Convento de Ntra. Sra. de las Huertas, conocido también como Convento de la Victoria, de mínimos de San Francisco de Paula. Estos religiosos se establecieron en 1510 en el Santuario de Santa María de las Huertas (ocupado anteriormente por mujeres emparedadas), situado a extramuros frente a la Puerta de Gallegos, en el extremo occidental de la ciudad. Con posterioridad la comunidad alzaría nueva iglesia con portada manierista, tal y como se aprecia en un dibujo del convento fechado en el siglo XIX. El cenobio disponía también de un claustro y de un amplio huerto.

En 1512 era fundado, detrás del Hospital de San Lázaro, el Convento de Ntra. Sra. de la Cabeza, de carmelitas calzados. Dado lo insalubre del lugar, la comunidad terminaría trasladándose en 1580 a la collación de la Magdalena. Allí quedó ubicada frente a la Puerta Nueva, sirviéndole de iglesia la ermita de Ntra. Sra. de la Cabeza, advocación que terminaría adoptando el cenobio. Contando con el patronazgo de los marqueses de Villaseca, a lo largo de siglo XVII se realizaron obras en el convento y posteriormente, durante el siglo XVIII, se convertiría en uno de los más importantes de la ciudad.

El ya citado Convento de los Santos Mártires, fundado bajo la Orden del Cister, quedaría desierto tras la muerte de su último abad, pasando en 1531 a los dominicos de Scala Coeli. El cenobio, aunque no era muy grande, poseía un bello claustro. El templo fue reedificado en 1575, convirtiéndose unos años más tarde en sus patronos los condes de Torres-Cabrera. En esta iglesia conventual recibiría también sepultura el humanista Ambrosio de Morales. ${ }^{17}$

Córdoba fue la primera urbe andaluza que contó con la presencia de los jesuitas. ${ }^{18}$ Los trámites para fundación de la Casa de la Compañía se iniciaron en 1552, fecha en la que el padre Antonio de Córdoba -hijo de los condes de Feria y marqueses de Priego- expresó a su madre, doña Catalina Fernández de Córdoba, su deseo de establecer en la ciudad un colegio de la Compañía. En un primer momento, éste quedó ubicado en el barrio del Alcázar, en la llamada Casa del Agua, lugar en donde el padre Antonio había vivido mientras residió en la capital cordobesa. Sin embargo, la fundación no llegaría a asentarse hasta dos años después, con motivo de la visita a la ciudad de San Francisco de Borja

${ }^{17}$ Sobre estos tres conventos véanse: Ramírez de Arellano y Gutiérrez, T. 1998: 49, 244-246 y 318. Ramírez y de las Casas-Deza, L. M. 1976: 192-200. Respecto al Convento de la Victoria, véase también Cosano Moyano, F. 1999: 178-179.

${ }^{18}$ Seguimos a Rodríguez G. de Ceballos, A. 2004. «Arquitectura y arquitectos en la provincia jesuítica de Andalucía», en F. García Gutiérrez (coord.), El arte de la Compañía de Jesús en Andalucía (1554-2004): 74-80. Córdoba: Caja de Ahorros y Monte de Piedad de Córdoba, Obra Social y Cultural. 
y su secretario, el padre Bartolomé Bustamante. Ambos fueron hospedados por el deán de la Catedral, don Juan de Córdoba -hijo del tercer conde de Cabra-, quien cedería sus casas para establecer allí el colegio. Éstas disponían de más espacio que la Casa del Agua y se hallaban en la collación de Santo Domingo de Silos. En 1564 se iniciaron las obras del conjunto arquitectónico en dicho enclave, el cual fue ampliado con la cesión de un solar por el Ayuntamiento.

Las primeras trazas fueron dadas por el padre Bustamente, siendo poco después modificadas por el arquitecto Hernán Ruiz el Joven. Otros jesuitas como Juan Bautista Villalpando, el hermano italiano Giuseppe Valeriano o el hermano Pedro Pérez, estuvieron relacionados también con la construcción de la iglesia y del colegio, siendo ampliado este último en el siglo XVIII.

Siguiendo el orden cronológico, hemos de referirnos a continuación al Convento de San José. Conocido popularmente como San Cayetano, su origen se remonta a 1586, fecha en la que San Juan de la Cruz fundaba un cenobio de carmelitas descalzos en la collación de Santa María. Los religiosos ocuparon una casa próxima a la antigua ermita de San Roque, que les sirvió de templo. En 1613 abandonaron este edificio que, pasando a propiedad de los carmelitas calzados, quedó convertido en un colegio para el estudio de Teología. Buscando el retiro espiritual los carmelitas descalzos se trasladaron a extramuros, frente a la Puerta del Colodro, a un terreno cedido por la Ciudad. Para ello, contaron con la protección de doña Beatriz de Haro y Portocarrero (viuda de don Pedro Venegas, señor de Luque, e hija del marqués del Carpio), quien adquirió el patronato de la iglesia y del convento. No obstante, las obras no serían concluidas hasta mediados del siglo XVII, efectuándose a comienzos del XVIII importantes reformas en las dependencias conventuales y en el templo. Éste constituye un buen ejemplo de arquitectura carmelitana, tal y como se aprecia en su estructura espacial, así como en su portada, cuyo diseño se muestra cercano a los esquemas ideados por fray Alberto de la Madre de Dios.

Doña Beatriz de Haro fundaría también en 1598 el Convento de San Juan Bautista, conocido por el Desierto, en una heredad que poseía en el término de Santa María de Trassierra. Perteneciente igualmente a la Orden de carmelitas descalzos, este cenobio sería abandonado por los religiosos dada la insalubridad del lugar. Con posterioridad volvería a ser poblado, si bien en 1760 quedaría extinguido definitivamente.

En la última década del siglo se fundaban el Convento de San Basilio y el Convento de Ntra. Sra. de la Zarza y San Lázaro el Real, de la Orden hospitalaria de San Juan de Dios. Los monjes de San Basilio encontraron dificultades para ocupar el Hospital de San Bartolomé, como era su deseo. Finalmente se establecieron en una casa del barrio del Alcázar viejo, donada para tal fin por el racionero Juan de Arriaza, en la que fundaron un colegio bajo la advocación de 
Ntra. Sra. de la Paz. El templo sería construido durante los siglos XVII y XVIII, tratándose del único edificio conservado del antiguo conjunto cenobial.

En 1590 surgía a extramuros, en un entorno perteneciente a la collación de la Magdalena, el Convento de Ntra. Sra. de la Zarza y San Lázaro el Real. El origen del mismo se encuentra en la ermita de Ntra. Sra. de la Zarza en la que, a finales del siglo XIII, el rey Sancho IV había fundado el Hospital de San Lázaro. Se justifica así el nombre de este cenobio, cuya fundación se debió a fray Baltasar de la Miseria, hijo de los marqueses de Camarasa, adoptando también la denominación de San Lázaro el Real por orden de Felipe II. Cerca del mismo sería trasladado en 1602 el ya citado Convento Madre de Dios. La insalubridad del entorno en donde este último había sido fundado en el siglo XV, motivó su mudanza a un enclave de la collación de Santiago, situado fuera de la muralla. A partir de entonces, este cenobio cobraría un mayor protagonismo en la vida y en la imagen de la ciudad. Siendo una buena muestra de la arquitectura barroca cordobesa, su templo no llegaría a concluirse y junto a las demás dependencias conventuales sería muy castigado posteriormente. ${ }^{19}$

Otros cenobios masculinos surgidos durante el siglo XVII fueron el Convento de Ntra. Sra. de Gracia, de trinitarios descalzos; el Convento del Santo Ángel, de franciscanos capuchinos; el Convento de San Pedro de Alcántara, de franciscanos alcantarinos y el Oratorio de San Felipe Neri: ${ }^{20}$

El primero fue fundado en 1607 por el reformador de los trinitarios, San Juan Bautista de la Concepción. Quedó establecido en la collación de San Lorenzo en las proximidades de la Puerta de Plasencia, situada en el ámbito oriental de la muralla. En dicho enclave, los religiosos ocuparon una pequeña vivienda junto a la ermita de Ntra. Sra. de Gracia, erigida a finales del siglo XV o principios del XVI. Dicho templo sería donado por el obispo Diego de Mardones a la comunidad en 1608, dando finalmente nombre al convento. A lo largo del Seiscientos y durante la primera mitad del Setecientos, los trinitarios añadirían al primitivo cenobio otras casas y solares; e incluso, algunas calles de la trama urbana concedidas por el Cabildo Municipal, ampliando además su huerta. En esta etapa se alzaron también el templo actual y las dependencias conventuales. La iglesia fue iniciada en la primera mitad del siglo XVII, consagrándose en 1686. No obstante, con posterioridad habrían de construirse y ampliarse todavía algunas capillas, además de efectuarse gran parte del exorno interior. Siendo uno de los principales edificios del Barroco cordobés, el templo muestra una fachada

\footnotetext{
${ }^{19}$ Respecto a estos cinco conventos véanse: Ramírez de Arellano y Gutiérrez, T. 1998: 41, 117-119, 247-249 y 568-569. Ramírez y de las Casas-Deza, L. M. 1976: 177-178, 197-198 y 200-205.

${ }^{20}$ Cfr. Ramírez de Arellano y Gutiérrez, T. 1998: 64-67, 404-405, 405-466 y 570-571. Ramírez y de las Casas-Deza, L. M. 1976: 205-209 y 239. Sobre el cenobio de trinitarios descalzos véase también Porres Alonso, B. 1998. Nuestra Señora de Gracia. Un convento cordobés del XVII: 23-37 y 39-68. Córdoba: Caja de Ahorros y Monte de Piedad de Córdoba, Obra Social y Cultural.
} 
rematada por tres frontones triangulares. A ambos lados de la misma se sitúan las portadas de acceso al antiguo recinto conventual, muy transformado tras las exclaustraciones decimonónicas.

En 1629 se establecían también en Córdoba los franciscanos capuchinos, trayendo licencia del rey y del nuncio para fundar cenobio. La comunidad ocupó provisionalmente el Hospital de los Desamparados, trasladándose en 1633 al edificio conventual. El origen de este claustro estuvo en unas antiguas casas en estado ruinoso, que poseía don Francisco Centurión y Fernández de Córdoba, marqués de Almunia, en una plaza de la collación de San Salvador, situada en las proximidades del lienzo septentrional de la muralla. El primer guardián del convento, fray Félix de Granada (que pertenecía a la familia de los duques de Nájera), compraría dichas casas por mil ducados con el fin de construir en ellas el convento. En 1638 se iniciaban las obras del templo, cuya sencilla fachada pasó a presidir la citada plaza que, a partir de entonces, sería conocida como Plaza de los Capuchinos.

El Convento de San Pedro de Alcántara, de franciscanos alcantarinos, tuvo igualmente su origen en un inmueble doméstico. Su fundación, a finales del Seiscientos, se debió a don Francisco Antonio de Bañuelos y Murillo, maestrescuela de la Catedral. Este religioso cedió a la comunidad sus casas situadas en la collación de San Bartolomé, próximas a la ermita de dicha advocación. En lo sucesivo, los frailes irían ampliando sus dependencias con la adquisición de casas contiguas, logrando también del Cabildo Municipal la cesión de un terreno para la construcción del templo, concluido en 1696. Pese a la sencillez estructural del mismo, constituye un ejemplo representativo de la arquitectura barroca en Córdoba.

La fundación del Oratorio de San Felipe Neri, también a fines del siglo XVII, se debió a don Luis Antonio Belluga y Moncada, canónigo lectoral de la Catedral de Córdoba y posteriormente cardenal. Este religioso compró con facultad real la casa de los Venegas de Henestrosa, un bello edificio del siglo XVI situado en la collación de Onmium Sanctorum. En 1695 se erigió junto al mismo la iglesia, atribuida a Francisco Hurtado Izquierdo, tratándose de otro exponente arquitectónico del Barroco cordobés. ${ }^{21}$

Respecto a las clausuras femeninas fundadas durante las centurias modernas, hemos de referirnos en primer lugar al Monasterio de la Anunciación de Ntra. Sra., conocido popularmente como Monasterio de la Encarnación. En 1503 el Dr. don Antón Ruiz de Morales, chantre y canónigo de la Catedral, cedía por testamento a su sobrina, Juana de Morales, unas casas que poseía en la collación de Santa María para el establecimiento de un beaterio. Este habría de regirse

\footnotetext{
${ }^{21}$ Vid. Taylor, R. 1986. «San Felipe Neri», en M. Peláez del Rosal y C. Pérez Almenara (eds.), El Barroco en Andalucía. III Curso de Verano: 100. Córdoba: Universidad de Córdoba.
}

Hispania Sacra, LXIV

129, enero-junio 2012, 29-66, ISSN: 0018-215-X, doi: 10.3989/hs.2012.002 
por la misma Juana de Morales y, tras su muerte, por el Cabildo Catedralicio. Seis años después, previa petición al pontífice Julio II, la comunidad se acogía a la Regla del Cister. Al igual que en caso del citado Monasterio de la Concepción, las disposiciones testamentarias quedaron alteradas. Lo que en principio iba a ser un beaterio de doce mujeres, terminó convirtiéndose en un cenobio de religiosas cistercienses. Esto justifica también los problemas que surgieron posteriormente: los escasos medios para mantener una comunidad más numerosa que la del originario beaterio y la falta de espacio para alojarla. Este último inconveniente se resolvió con la incorporación al monasterio de un corral y un palacete, pertenecientes al Cabildo.

Muy próximo a las religiosas de Santa Clara, el Monasterio de la Encarnación supuso una pieza urbanística más, en el proceso de sacralización del ámbito oriental de la collación de Santa María. En la actualidad se conservan muy escasos restos de la primitiva clausura, que fue sometida durante el siglo XVIII a una profunda transformación.

Como indicamos anteriormente, la bula fundacional otorgada por el papa Julio II en 1506, vino a modificar las disposiciones establecidas por doña Beatriz de los Ríos en su testamento para la fundación del Monasterio de la Concepción. A este respecto, este claustro femenino pasaría a regirse por la Regla del Cister, en vez de por la Regla de Santo Domingo. Asimismo, el acondicionamiento de las casas de la fundadora a la clausura no se efectuaría hasta mediados de esta centuria. Unos años más tarde quedaría incluido en el cenobio el vecino Hospital de San Bartolomé. Tal incorporación estuvo motivada por el perjuicio que ocasionaba su proximidad, registrándose desde el mismo las dependencias de las religiosas. Incluso, llegó a darse la circunstancia de que algunos hombres, huyendo de la justicia, entraban en la clausura a través de este edificio asistencial. En las estancias del mismo quedarían ubicados la enfermería y otros aposentos del monasterio. ${ }^{22}$

En los primeros años del Quinientos se fundaba también el desaparecido Convento de Santa María de las Nieves, de monjas agustinas, cuyo primer emplazamiento estuvo en la collación de San Lorenzo, en plena Ajerquía cordobesa. En 1532 sería trasladado a la Villa, concretamente a la collación de San Salvador. El lugar elegido fue la actual calle Alfonso XIII, que acabaría adoptando

${ }^{22}$ Sobre estos dos monasterios véanse: Ramírez de Arellano, T. 1998: 563. Ramírez y de las CasasDeza, L. M. 1976: 215. Orti Belmonte, M. A. 1980. Córdoba monumental, artística e histórica: 452453. Córdoba: Diputación Provincial de Córdoba. (Segunda edición). Cerrato Mateos, F. 2006: 50-57. Respecto al Monasterio de la Encarnación, véanse también los siguientes estudios: Cerrato Mateos, F. 2011. «El monasterio de la Encarnación de Córdoba. Universalidad y originalidad de una fundación cisterciense», en F. J. Campos y Fdez. de Sevilla (coord.), La clausura femenina en el Mundo Hispánico: Una fidelidad secular. Actas del Simposium II: 725-739. San Lorenzo del Escorial (Madrid): R.C.U. Escorial-M ${ }^{a}$ Cristina, Servicio de Publicaciones. Raya Raya, M. A. 2011. «El monasterio cisterciense de Nuestra Señora de la Encarnación de Córdoba: estudio artístico», en Ibídem: 741-757. 
el nombre del cenobio. Frente al mismo se encontraba el Convento del Espíritu Santo, de religiosas dominicas, cuyo origen estuvo en un beaterio fundado en 1521 por doña Beatriz de Sotomayor, hija de don Luis Méndez de Sotomayor, señor de El Carpio y de Morente. A principios del siglo XVII el pontífice Paulo $\mathrm{V}$ elevaba esta fundación a convento, sirviéndoles a las religiosas para el culto la vecina iglesia parroquial de San Salvador. Dicho templo quedaría integrado en la clausura en 1782, al fusionarse las parroquias de San Salvador y Santo Domingo de Silos en la antigua iglesia de la Compañía.

En 1508 había surgido otro claustro de dominicas bajo el patronato de la Casa del Carpio: el Convento de Jesús Crucificado. Su origen estuvo en un hospital para treinta y tres mujeres fundado en 1496 en la collación de Santa María, en las casas de doña María de Sotomayor (hermana de doña Beatriz de Sotomayor, fundadora del citado Convento del Espíritu Santo), según lo dispuesto en su testamento. Posteriormente, la comunidad abandonaría este emplazamiento estableciéndose en una casa de los Señores del Carpio, ubicada en la misma collación. El templo conventual fue construido durante siglo XVI, siendo concebido también como enterramiento de los miembros de la Casa del Carpio. El claustro debió de comenzarse en esta misma centuria, si bien la parte superior parece ser del siglo XVIII.

En la collación de Santo Domingo de Silos surgiría también el Convento de Jesús y María, de religiosas mínimas de la Orden de San Francisco de Paula. Su fundación en 1538 se debió a doña María Carrillo y Hoces, viuda de don Bernardino de Sotomayor. No habiendo llegado hasta nosotros, son muy escasas las referencias sobre este conjunto conventual.

La Villa seguiría acogiendo nuevos claustros femeninos, especialmente desde finales del Quinientos y hasta mediados del Seiscientos. Nos encontramos ante una nueva época prolífica en fundaciones religiosas, que consolidaron la fisonomía sacralizada de la Córdoba Moderna. A esta etapa corresponde el nacimiento de las siguientes clausuras: el Convento de Santa Ana, de carmelitas descalzas; el Convento del Corpus Christi, de dominicas recoletas; el Convento de San Rafael, de franciscanas recoletas; y los cistercienses de San Martín y Ntra. Sra. de la Concepción. Por su parte, la Encarnación Agustina sería el único cenobio femenino establecido en la Ajerquía durante la Edad Moderna. ${ }^{23}$

\footnotetext{
${ }^{23}$ Sobre estos últimos conventos femeninos véanse: Ramírez de Arellano y Gutiérrez, T. 1998: 201, 333-334, 398-400, 415-416, 420, 429, 540-541, 555-556 y 569. Ramírez y de las Casas-Deza, L. M. 1976: 22, 217-219 y 221-222. Orti Belmonte, M. A. 1980: 387-391, 404-407 y 443-447. Escobar Camacho, J. M. 1989: 129. Jordano Barbudo, M. A. 1996: 202-204 y 221-227. Jordano Barbudo, M. A. 2002: 164-179 y 190-191. Moreno Cuadro, F. y Palencia Cerezo, J. M. 1989. San Juan de la Cruz y Córdoba. El convento de Santa Ana. Catálogo de la exposición conmemorativa del Cuarto Centenario de la Fundación del Convento de Carmelitas Descalzas de Santa Ana de Córdoba, 1589-1989. Córdoba: Monte de Piedad y Caja de Ahorros de Córdoba. Villar Movellán, A. (dir.). 1997. El Convento de
} 
El Convento de Santa Ana fue fundado, en 1589, con el apoyo del obispo de Córdoba don Francisco Pacheco. Este claustro quedó ubicado en la collación de Santa María, en un enclave limítrofe con la de Santo Domingo de Silos. Allí existía una ermita bajo la advocación de Santa Ana, que se convertiría en el primer templo de las religiosas, dando igualmente nombre a la fundación. A esta ermita se le agregaron unas casas aledañas pertenecientes al marqués del Carpio, constituyendo tales edificios el núcleo originario del convento. Con el tiempo el cenobio fue adquiriendo una gran extensión, destacando un gran espacio dedicado a huerto. En 1608 se iniciaron las obras del nuevo templo, que sustituiría a la primitiva ermita, prosiguiéndose su construcción durante el siglo XVIII.

A principios del Seiscientos surgía en la collación de Santa María el Convento del Corpus Christi, cuyo origen estuvo también en una ermita. Su fundación en 1608 se debió al obispo Diego de Mardones, quien trajo cuatro monjas del convento de dominicas de Toledo, con el deseo de que en Córdoba hubiese un claustro de religiosas reformadas de la Orden de Santo Domingo. Para ello, donó la ermita de San Benito que había pertenecido a la Orden de Alcántara. Situada en la costana a la que daba nombre, desde entonces dicha vía sería conocida por la Cuesta del Corpus. Esta nueva comunidad de religiosas hubo de adaptarse al reducido espacio conventual, si bien, poco a poco, fue ampliando la clausura con la adquisición de inmuebles colindantes. La primera expansión tuvo lugar en 1628, veinte años después de la fundación del cenobio. En tal ocasión la comunidad pudo comprar, sin gran esfuerzo económico, la casa del caballero veinticuatro don Carlos Guajardo Fajardo.

En el transcurso de las siguientes centurias, las monjas del Corpus seguirían ensanchando sus dependencias con la incorporación al convento de otras casas aledañas, e incluso de algunas callejas de la trama urbana, que fueron adaptándose a la clausura. De este modo, el conjunto llegaría a ocupar una amplia manzana dominada por el edificio conventual, encajado entre varios espacios (el compás de acceso a la clausura, dos claustros, diversos patios, el cementerio y un huerto), destinados por las religiosas a diversos usos. De su arquitectura cabe destacar el templo y el claustro principal. El primero, de pequeñas dimensiones, fue alzado durante la primera mitad del siglo XVII. El claustro principal se erigió una vez concluidas las obras de la iglesia conventual, fechándose en el siglo XVIII.

Como apuntábamos más arriba, la Encarnación Agustina fue el único claustro femenino establecido en la Ajerquía. Su origen estuvo en un beaterio para el recogimiento de mujeres arrepentidas, fundado a mediados del siglo XVI en la collación de San Pedro. En 1636 pasaría a convertirse en convento, adoptando

Dominicas del Corpus Christi de Córdoba (1609-1992). Córdoba: CajaSur. Cerrato Mateos, F. 2006: 49-51, 57-59 y 251-262. 
la Regla de San Agustín. Sin embargo, dados sus orígenes fue siempre mal mirado, llegando su calle a denominarse de las Arrecogidas.

Mayor trascendencia en la vida de la capital cordobesa tendrá el Convento de San Martín. Su fundación en 1635 se debió a don Martín Gómez de Aragón, jurado de la collación de San Lorenzo y viudo de doña Leonor de Aragón. El matrimonio no tuvo hijos, pero dispuso de una considerable fortuna que destinó a la creación de una fundación piadosa. En su testamento don Martín Gómez de Aragón instituía un patronato de legos, por expreso deseo de su difunta esposa, así como un colegio de niñas huérfanas y un convento. El edificio de estos dos últimos habría de ser el mismo, si bien con departamentos diferenciados, contando cada uno con sus respectivas porterías y dependencias. Ambas fundaciones quedarían comunicadas a través del compás y la iglesia. Ésta debería contar con diferentes coros o tribunas, disponiendo su capilla mayor de dos enterramientos: el del lado del Evangelio, para él y su esposa; y el de la Epístola, destinado a los futuros patronos del convento. Para tal fundación designaba el solar de la Alcaicería, ubicado en las proximidades de su casa, en la collación de Santa María.

Se desconocen las razones por las que, una vez fallecido don Martín de Aragón, la fundación no se realizó en dicho solar. Fue entonces cuando los patronos adquirieron el Palacio de los marqueses de Comares, erigido tras la reconquista de la ciudad en la collación de San Nicolás de la Villa. Ocupando una gran extensión, se trataba de un bello edificio rodeado de almenas que, al ausentarse esta familia nobiliaria de Córdoba, había quedado deshabitado y en ruinas. El conjunto palaciego fue reformándose para su adaptación a la clausura, ya que el colegio finalmente no llegaría a fundarse por falta de fondos. Esto justifica también la lentitud de las obras, hallándose en 1648 aún inconclusas.

El convento disponía de un gran patio de entrada con dos puertas: una de ellas abría a la misma calle de San Martín; la otra se hallaba frente a la iglesia parroquial de San Nicolás de la Villa. Asimismo, en la esquina de la calle de la Paciencia había un mirador. El templo, cuya puerta daba a la calle de la Morería, era de medianas dimensiones.

Otro cenobio establecido igualmente en un antiguo palacio fue el Convento de San Rafael, de franciscanas recoletas, conocido popularmente como Convento de Capuchinas. Este claustro fue fundado en 1655 por don Antonio Fernández de Córdoba Cardona y Aragón (noveno conde de Cabra y octavo duque de Sessa y de Baena), en una casa-palacio de su propiedad situada en la collación de San Salvador. Dicho palacio (cuya construcción se iniciara en la segunda mitad del siglo XIV), había pertenecido a su antepasado don Diego Fernández de Córdoba, I conde de Cabra. Como en el caso del ya citado Monasterio de Santa Marta, nos encontramos ante otro ejemplo de arquitectura mudéjar civil adaptada a la clausura. Tan sólo le sería añadido el templo, erigido en el siglo XVIII durante el 
obispado de don Marcelino Siuri, tratándose de un buen ejemplo de la arquitectura barroca en Córdoba. El conjunto conventual, que ocupa una gran extensión, consta de varios claustros y un huerto con alberca para el autoabastecimiento de la comunidad. El llamado claustro del magnolio constituía el patio principal del palacio originario, tratándose de un interesante exponente de arquitectura mudéjar.

La última comunidad en asentarse en la ciudad fue la del Convento de Ntra. Sra. de la Concepción -llamado también del Cister-, fundado en 1620 por el obispo de Málaga, don Luis Fernández de Córdoba, en la localidad cordobesa de Guadalcázar. La insalubridad del enclave que las religiosas ocuparon en esta villa, justifica su traslado a Córdoba en 1653, pese a carecer en la ciudad de un lugar en donde instalarse. Aun contando con la hospitalidad del marqués de Guadalcázar, se negaría a admitirlas doña Leonor de Acevedo, que residía en las casas de este noble, ubicadas en la Puerta del Rincón. De este modo, terminaron siendo acogidas por su administrador, el escribano Antonio Bravo de las Misas. A principios de los años sesenta la comunidad adquiría una vivienda deshabitada, perteneciente a una capellanía, situada en la collación de San Salvador. Asimismo, durante estos años fue ampliando la clausura con la adquisición de cuatro viviendas contiguas.

Una figura clave en la historia de este convento cisterciense fue la del obispo don Marcelino Siuri. Gracias a su aportación económica, entre 1725 y 1729 fue erigido el templo, tratándose de un buen ejemplo de la arquitectura barroca en Córdoba. Este prelado permitió también la reedificación del cenobio, dada la estrechez de las dependencias de clausura. Cabe recordar, que el convento había sido alzado sobre la muralla que separaba la Villa de la Ajerquía. Tanto la muralla como la calle constituían un gran obstáculo para su ampliación, justificándose así la estrecha y larga manzana que llegaron a ocupar las monjas del Cister.

De las fundaciones religiosas de la Córdoba Moderna (véanse Cuadros 3 y 4 ) se deducen ciertas similitudes respecto a las efectuadas durante la etapa bajomedieval. Sin embargo, también se aprecian diferencias significativas:

Las comunidades masculinas siguieron ubicándose tanto fuera como dentro del recinto murado, optando en este último caso por la Villa o zona occidental de la ciudad. En la Ajerquía tan sólo llegaría a fundarse un claustro de monjas: el Convento de la Encarnación Agustina. Las restantes clausuras femeninas quedaron concentradas en la Villa, principalmente en las collaciones de San Salvador y Santa María.

Tras este recorrido por las fundaciones religiosas de la Córdoba Moderna, se explica el hecho de que esta capital ofreciese a mediados del Setecientos un marcado paisaje conventual, ante la abundancia de conjuntos cenobiales en su espacio urbano. A ello contribuyeron especialmente las comunidades femeni- 
nas, siendo una de las ciudades españolas con un mayor número de conventos de monjas (un total de 20); una cifra sólo superada en Andalucía por Sevilla, que llegó a poseer hasta 27 claustros femeninos. ${ }^{24}$

La imagen de la Córdoba conventual queda bien ilustrada en la Figura 1. En ella reproducimos el Plano de los Franceses de 1811 (primer documento gráfico de la ciudad), indicando la ubicación de las fundaciones religiosas efectuadas desde las centurias bajomedievales hasta el siglo XVIII. En este plano puede observarse la concentración cenobial existente en algunos ámbitos de la ciudad, especialmente en la Villa. Cabe destacar la gran proximidad que muestran las clausuras de San Rafael y El Cister, con las ya desaparecidas de Nuestra Señora de las Nieves, Espíritu Santo y Santa María de las Dueñas.

\section{LAS DESAMORTIZACIONES ECLESIÁSTICAS Y EL SURGIMIENTO DE UNA NUEVA URBE}

Se ha considerado al siglo XIX como la centuria de las exclaustraciones, cobrando especial importancia la decretada por el ministro Mendizábal entre 1835 y 1836. No obstante, antes de que diera comienzo esta centuria, tuvieron lugar unos acontecimientos que, de hecho, constituyen un claro antecedente de todo el proceso desamortizador decimonónico.

El clero regular viviría durante el reinado de Carlos III una etapa difícil, sobre todo las órdenes mendicantes, afectadas por diversos problemas internos que vinieron a provocar su desprestigio. Se justifican así las reformas emprendidas por este monarca, especialmente en las comunidades masculinas. De entre todas, la Compañía de Jesús pasaría a convertirse en punto de mira, al ser acusada de intervenir en distintos asuntos políticos en contra de la monarquía. Tales motivos, provocaron su supresión el 3 de abril de 1767.

Si bien durante el siglo XVIII se emprendieron algunas medidas desamortizadoras, que afectaron a aquellos bienes en poder de las llamadas «manos muertas» (tierras y otras posesiones pertenecientes a la nobleza, e incluso a la Iglesia, que no producían ninguna riqueza), la expulsión de los jesuitas fue realmente el punto de partida de la política de incautación de los bienes eclesiásticos. Tal acontecimiento, constituyó un claro anticipo de las consecuencias que sobre el espacio urbano podían tener la exclaustración y la enajenación de los bienes de la Iglesia. De hecho, los establecimientos jesuíticos fueron confiscados, pasando sus bienes a la Corona. Los edificios que hasta entonces habían pertenecido a la Compañía fueron destinados a escuelas, teatros, casas de huéspedes, etc., mientras que las iglesias siguieron abiertas al culto como parroquias o ayudas

\footnotetext{
${ }^{24}$ Vid. Atienza López, A. 2009. «Nuevas consideraciones sobre la geografía y la presencia conventual en la España Moderna. Otras facetas más allá de la concentración urbana». Hispania Sacra 123: 59. 
de parroquias próximas, siendo también, en algunos casos, entregadas a otras órdenes religiosas. ${ }^{25}$

En Córdoba, el obispo Yusta Navarro destinó el antiguo templo de los Jesuitas, en 1782, a sede de las refundidas parroquias de Santo Domingo de Silos y San Salvador. Respecto al colegio, en un principio se dispuso convertirlo en hospicio de pobres. Sin embargo, sacado el edificio a subasta, fue comprado por el deán Francisco Javier Fernández de Córdoba. Este religioso fundaría en el mismo las llamadas Escuelas Pías en 1787. ${ }^{26}$

La invasión francesa y el reinado de José Bonaparte tuvieron nefastas consecuencias para nuestro patrimonio histórico-artístico, siendo especialmente castigados los edificios religiosos.$^{27}$ El saqueo y la posterior ocupación de templos y cenobios por los ejércitos napoleónicos, fueron hechos que se generalizaron en casi toda España, a excepción de territorios como Galicia que escaparon del dominio francés y del consecuente cierre de conventos y monasterios. Las medidas desamortizadoras aplicadas entonces, tuvieron como fin disminuir la deuda pública del Estado. Tales medidas quedaron expuestas en una serie de decretos, que fueron sucediéndose entre 1808 y 1810, destacando el emitido el 18 de agosto de 1809 , que ordenaba la supresión, en un plazo de quince días, de todas las órdenes regulares, mendicantes y clericales. Si bien no fueron muchos los edificios religiosos derribados entonces, al Estado le resultaba imposible conservar adecuadamente tantos inmuebles, hallándose aquí el origen de la oleada destructora que llegaría años más tarde y que provocaría la desaparición total o parcial de muchos conjuntos cenobiales.

En general, los procesos desamortizadores de los invasores afectaron más a las comunidades masculinas que a las femeninas. Las autoridades francesas no sabiendo qué hacer con las monjas, menos preparadas que los religiosos para desenvolverse en aquella sociedad, tendieron a dejarlas en sus conventos, despojadas de gran parte de sus bienes. En Córdoba los cenobios femeninos no fueron exclaustrados, si bien quedaron desamortizados de sus bienes y en una situación de gran pobreza. ${ }^{28}$ Tal panorama se evidencia en el ya citado Plano de

${ }^{25}$ Vid. Domínguez Ortiz, A. 1988. Carlos III y la España de la Ilustración: 66-83. Madrid: Alianza. Rodríguez G. de Ceballos, A. 2002. La arquitectura de los Jesuitas: 118-120. Madrid: Edilupa.

${ }^{26}$ Sobre la desamortización de los jesuitas en Córdoba resulta de gran interés el estudio de Vázquez Lesmes, R. 2007. «Extrañamiento de los jesuitas y desamortización de sus temporalidades en Córdoba (1767-1769)», en F. J. Campos y Fdez. de Sevilla (dir.), La desamortización: El expolio del patrimonio artístico y cultural de la Iglesia en España. Actas del Simposium: 241-258. San Lorenzo del Escorial (Madrid): R.C.U. Escorial-M ${ }^{\mathrm{a}}$ Cristina, Servicio de Publicaciones.

${ }^{27}$ Seguimos a Barrios Rozúa, J. M. 1998. Reforma urbana y destrucción del patrimonio histórico en Granada. Ciudad y Desamortización: 85-93. Granada: Universidad de Granada. Junta de Andalucía.

${ }^{28}$ Vid. Nieto Cumplido. J. M. 2003. «La Iglesia de Córdoba», en J. M. Nieto Cumplido (coord.), Iglesias de Córdoba y Jaén. Historia de las Diócesis Españolas, Vol. 8: 160. Madrid: Biblioteca de Autores Cristianos. Córdoba: CajaSur. 
los Franceses de 1811, documento gráfico de Córdoba realizado por el barón de Karvinski por encargo del Ayuntamiento. ${ }^{29}$ El cenobio de carmelitas calzados fue uno de los más castigados por la ocupación francesa, al igual que los conventos de Gracia y Madre de Dios. Las dependencias de este último fueron utilizadas como acuartelamiento de las tropas. ${ }^{30}$

Posteriormente, ante la nefasta situación de la Hacienda, las Cortes de Cádiz aplicarían también su propia desamortización, si bien no llegaría a tener el alcance de la emprendida por José Bonaparte. De este modo, y pese al ambiente anticlerical, ya desde 1813 se produciría la vuelta de los religiosos a sus cenobios. ${ }^{31}$

Pero poco va a durar la tranquilidad en los conventos, ya que, forzado el Rey por las circunstancias, habrá un nuevo intento de supresión durante el trienio constitucional (1820-1823). ${ }^{32}$ Sin embargo, mayores serán las secuelas de la Desamortización de Mendizábal, afectando tanto a los conventos de religiosos como a los de religiosas. Ante la nefasta situación de la Hacienda, en 1835 fueron exclaustrados todos los conventos y monasterios masculinos, excepto los dedicados a la beneficencia y a las misiones. Las propiedades de dichos cenobios serían aplicadas al año siguiente a la extinción de la deuda. En 1837 se haría lo mismo con los bienes de las órdenes femeninas, dado que también se dispuso el cierre de aquellas clausuras que tuviesen menos de 20 religiosas profesas, no permitiéndose en una misma ciudad dos o más claustros de una misma orden. Los edificios conventuales y fincas confiscados por el Estado pasarían a denominarse Bienes Nacionales. Vendidos éstos mediante subasta pública, se convertirían en bienes de propiedad particular. ${ }^{33}$ En los espacios desvinculados surgirá la ocasión de

\footnotetext{
${ }^{29}$ Sin embargo, en dicho documento se omiten algunos cenobios. Desconocemos las razones por las que no se indican en el mismo el Monasterio de San Pedro el Real y el Convento de la Merced (que no figuran como exclaustrados, tal y como aparecen los restantes cenobios masculinos), así como las clausuras femeninas de Santa Ana, Jesús y María, San Rafael, Santa María de las Dueñas, Santa Isabel de los Ángeles, Santa Inés y Regina Coeli.

${ }^{30}$ Cfr. Ramírez de Arellano y Gutiérrez, T. 1998: 49. Aranda Doncel, J. 2007. «Las exclaustraciones de las órdenes religiosas en la Córdoba del primer tercio del siglo XIX: el convento de los terciarios regulares de San Francisco», en F. J. Campos y Fdez. de Sevilla (dir.), La desamortización: El expolio del patrimonio artístico y cultural de la Iglesia en España. Actas del Simposium: 269-273. San Lorenzo del Escorial (Madrid): R.C.U. Escorial-M ${ }^{\mathrm{a}}$ Cristina. Servicio de Publicaciones. Porres Alonso, B. 1998: 145-153.

${ }^{31}$ Sobre la desamortización de las Cortes de Cádiz véase Barrios Rozúa, J. M. 2007. «Los conventos andaluces frente a la desamortización de las Cortes de Cádiz y el anticlericalismo», en F. J. Campos y Fdez. de Sevilla (dir.), La desamortización: El expolio del patrimonio artístico y cultural de la Iglesia en España. Actas del Simposium: 120-138. San Lorenzo del Escorial (Madrid): R.C.U. Mª CristinaServicio de Publicaciones.

${ }^{32}$ Fraga Iribarne, M. L. 1993. Conventos femeninos desaparecidos. Arquitectura religiosa perdida durante el siglo XIX en Sevilla: 45. Sevilla: Guadalquivir.

${ }^{33}$ Cfr. Martí Gilabert, F. 2003. La desamortización española: 42-52. Madrid: Rialp. Seguimos también a Sobrón Elguea, M. C. 2004. Impacto de la desamortización de Mendizábal en el paisaje urbano de Zaragoza: 11-12 y 39-55. Zaragoza: Institución Fernando el Católico.
}

Hispania Sacra, LXIV

129, enero-junio 2012, 29-66, ISSN: 0018-215-X, doi: 10.3989/hs.2012.002 
emplazar servicios públicos (mercados, hospitales, cuarteles, etc.), para los que anteriormente era difícil encontrar lugar; igualmente se posibilitará la creación de espacios libres o bien la apertura de nuevas calles descongestionadoras de algunas zonas muy saturadas por la edificación, y, por último, se estará ofreciendo un terreno para la construcción de viviendas en aquellas ciudades que lo están demandando, efectuándose así el ensanche interior de las poblaciones. ${ }^{34}$

En Córdoba fueron exclaustrados y posteriormente vendidos varios cenobios. Adquiridos algunos por instituciones públicas, otros pasaron a manos de particulares. Aquellos situados en los alrededores de Córdoba sufrieron también los efectos de la desamortización. No obstante, careciendo de interés especulativo con fines urbanísticos, la destrucción de los mismos estuvo más bien motivada por el abandono y el olvido. Tal fue el caso del Convento de Santo Domingo de Scalacoeli y del Monasterio de San Jerónimo del Valparaíso. Este último pasó a depender del Estado, siendo vendido posteriormente en 1871 a particulares. El Convento de San Francisco de la Arruzafa sería comprado también por un particular, que lo reparó y convirtió en una fonda rural. ${ }^{35}$

Los edificios de algunas órdenes masculinas pasaron a ejercer funciones militares o de beneficencia. El Oratorio de San Felipe Neri y el recinto cenobial de la Trinidad se destinaron a cuarteles. La iglesia de este antiguo monasterio sería utilizada como ermita y posteriormente, desde 1877, como nueva sede parroquial de las parroquias de Omnium Sanctorum y San Juan, fusionadas en 1799. El edificio que perteneciera a la Orden hospitalaria de San Juan de Dios fue destinado al ejército. De hecho, antes incluso de la exclaustración el hospital había estado dedicado a la curación de militares. Posteriormente, en 1867, quedaría destruido por un gran incendio.

El Ex-convento de Ntra. Sra. de la Merced se destinó a hospicio, sufriendo profundas transformaciones. El edificio de los religiosos alcantarinos se convirtió en casa de vecinos, siendo más tarde solicitado por la Junta de Beneficencia para ampliar la casa de dementes. Las dependencias del Convento Madre de Dios fueron ocupadas durante más de veinte años por una fábrica de cristales. Posteriormente, en 1864, acogerían un asilo de mendicidad. Por su parte, la iglesia seguiría abierta al culto, como ayuda de la parroquia de Santiago, en la zona extramuros de este barrio. El templo de los basilios quedaría también como auxiliar de la parroquia del Sagrario, siendo derruidas las dependencias de los religiosos. Igualmente, continuarían abiertos al culto los antiguos templos de carmelitas calzados, carmelitas descalzos y capuchinos. Con el tiempo, estas dos últimas comunidades volverían a recuperar sus edificios.

\footnotetext{
${ }^{34}$ García Verdugo, F. R. 1992. Córdoba, Burguesía y Urbanismo. Producción y Propiedad del Suelo Urbano: El Sector de Gran Capitán, 1859-1936: 77. Córdoba: Ayuntamiento de Córdoba, Gerencia de Urbanismo.

${ }^{35}$ Vid. Gracia Boix, R. 1973: 104-118. Ramírez y de las Casas-Deza, L. M. 1976: 194.
} 
El antiguo Monasterio de San Pablo sería destruido en su mayor parte, destinándose muchos de sus materiales a la construcción de otros edificios. Afortunadamente, la iglesia se libraría de la piqueta. Peor suerte correría el Ex-convento de los Santos Mártires, cuyo templo fue cerrado al culto, asumiendo diversas funciones (almacén de maderas, fábrica de lienzos, teatro de aficionados, etc.). Tanto la iglesia como las antiguas dependencias conventuales serían finalmente adquiridas por el Ayuntamiento, que procedió a su derribo. En su solar se abriría un camino de ronda que llevaría, precisamente, el nombre de los Mártires. ${ }^{36}$

La exclaustración llegaría igualmente al Convento de Nuestra Señora de Gracia, siendo también incautada por el Estado la amplia huerta que poseían los religiosos. El edificio quedó sin uso hasta que fue destinado a presidio correccional. En un principio, al no ser suficientes para tal función las antiguas dependencias conventuales, se pensó dedicar también a dicho fin el templo. Tal idea no prosperaría y la iglesia continuaría abierta al culto. La existencia del presidio sería más bien breve, ya que en 1843 sería suprimido. Posteriormente, el piso bajo del antiguo cenobio sería empleado para el alojamiento de los caballos sementales, quedando el resto del edificio abandonado y amenazando ruina. En lo sucesivo, el ex-convento serviría también de hospital y para otras funciones. En 1866 tres religiosos intentaron erigirlo nuevamente en cenobio trinitario, sin obtener el apoyo suficiente. Diez años más tarde se establecerían en el mismo los Padres Claretianos. ${ }^{37}$

Las clausuras femeninas sufrieron también los efectos de la desamortización de Mendizábal, siendo suprimidos algunos cenobios de religiosas. Tal es el caso del Convento de Regina Coeli, cuyas dependencias quedaron convertidas en casa de vecinos, al tiempo que la iglesia ejerció diversas funciones: primero fue teatro, después fábrica de paños, almacén de tocino y también cuartel. Similar destino tuvo el Convento de Santa Inés, utilizándose su templo como pajar y el resto del inmueble como provisión, teatro, posada y, por último, como casa de vecinos. Parte del que fuese Convento de Jesús y María quedó convertido igualmente en casa de vecinos, así como en depósito de cuadros del Museo Provincial. Posteriormente, fue adquirido por un particular que estableció en el mismo

\footnotetext{
${ }^{36}$ Sobre el devenir de los edificios de estas órdenes masculinas véanse: Ramírez y de Arellano y Gutiérrez, T. 1998: 157, 246, 362 y 571. Ramírez y de las Casas-Deza, L. M. 1976: 171, 178, 184, 194, 200 y 201. Aranda Doncel, J. 2007: 274-275. Martín López, C. 1990. Córdoba en el siglo XIX. Modernización de una trama urbana: 143-148 y 272-277. Córdoba: Ayuntamiento de Córdoba, Gerencia de Urbanismo. Porres Alonso, B. 2007: 180. Palencia Cerezo, J. M. 1995. Setenta años de intervención en el patrimonio histórico-artístico cordobés (1835-1905): 64-67. Córdoba: Caja de Ahorros y Monte de Piedad de Córdoba.

${ }^{37}$ Estos religiosos ocuparían el Ex-convento de Gracia desde 1876 a 1903. En este último año los trinitarios recuperaban nuevamente el edificio, destinándolo entonces a colegio de filosofía. Posteriormente, desde 1969, el antiguo templo conventual pasaría a ejercer como parroquia. Asimismo, en 1972 las dependencias de los trinitarios se convertían en colegio de enseñanza, estableciéndose también al año siguiente un noviciado. Cfr. Porres Alonso, B. 1998: 147-167.
}

Hispania Sacra, LXIV

129, enero-junio 2012, 29-66, ISSN: 0018-215-X, doi: 10.3989/hs.2012.002 
una fábrica de tejidos. La iglesia estuvo dedicada a teatro y después a taller de carpintería, existiendo otro taller de coches en las dependencias conventuales.

Los antiguos cenobios de Nuestra Señora de las Nieves y del Espíritu Santo, estuvieron a punto de ser derribados para convertir sus respectivos espacios en plazas. Sin embargo, ante la urgente necesidad de dinero, terminaron siendo vendidos por la Junta de Enajenación. El primero se convirtió en Liceo artístico y literario, debiendo reedificarse entonces el inmueble al encontrarse en un estado lamentable. En 1853 se estableció en el mismo el Círculo de la Amistad, institución cultural surgida en fusión con la anterior, que ha prevalecido hasta nuestros días. Respecto al edificio del que fuese Convento del Espíritu Santo, primeramente fue derruida una porción del mismo para ensanchar la calle Azonaicas. El resto sería igualmente demolido para construir, en 1845, un mercado que tan sólo funcionó unos años, encontrándose ya en 1860 abandonado y ruinoso.

La mayor parte de los ejemplos citados terminaron siendo arrasados, permitiendo con ello la creación de nuevos espacios urbanos. Este mismo final aguardó al antiguo conjunto cisterciense de San Martín. Adquirido por el Ayuntamiento, fue derribado con el fin de trazar sobre su solar el Paseo de San Martín, concebido como «paseo de salón», aislado y cerrado del resto del espacio público. En este mismo enclave urbano sería trazado posteriormente, entre 1859 y 1869, el Paseo del Gran Capitán. Este último supuso un interesante proyecto de expansión urbana, que permitió comunicar los barrios históricos con la estación de ferrocarril, ubicada desde mediados del Ochocientos en el extremo noroccidental de la ciudad. ${ }^{38}$

El antiguo Monasterio de San Pedro el Real, constituye uno de los ejemplos más singulares desde el punto de vista urbanístico. ${ }^{39}$ Este cenobio se vio implicado en un largo proceso acerca de su destino, perdiendo finalmente la mayor parte de su arquitectura. Suprimido por las Cortes de Cádiz, volvería a ser entregado a la comunidad en 1813. Sin embargo, con la desamortización de Mendizábal quedaría definitivamente exclaustrado.

Tras un intenso debate sobre el uso que habría de darse al antiguo monasterio franciscano, en 1842 sería vendido junto con su huerto. Alquilado por su

\footnotetext{
${ }^{38}$ Respecto al fin que deparó a estas clausuras femeninas véanse: Ramírez de Arellano y Gutiérrez, T. 1998: 32, 200, 202, 420-422 y 429. Ramírez de Arellano, R. 1983: 182. Ramírez y de las Casas-Deza, L. M. 1976: 122, 125-126, 211 y 221-222. Anguita González, J. 1984. La desamortización eclesiástica en la ciudad de Córdoba (1836-1845): 31-32, 87-88 y 91. Córdoba: Albolafia. Palencia Cerezo, J. M. 1995: 36. Martín López, C. 1990: 90-94, 159-165 y 193-196. García Verdugo, F. R. 1992: 77-82. García Verdugo, F. R. 1997. «El entorno urbano en los siglos XIX y XX», en A. Villar Movellán (dir.) 1997: 97.

${ }^{39}$ Cfr. Anguita González, J. 1984. 85-88. Castellano Cuesta, M. T. 1988: 22-24, 45-48, 61-64, 68 y 72-76. Martín López, C. 1990: planos $n^{\circ}$ II y n III. Castro Castillo, M. R. 1996. «La urbanización de la huerta de San Francisco en Córdoba», en M. Peláez del Rosal (dir. y ed.), El franciscanismo en Andalucía. Conferencias del II Curso de Verano San Francisco en la historia y en el arte andaluz: 45-49. Córdoba: Caja Madrid, Obra Social.
} 
propietario, en él se estableció una fábrica de paños, siendo después adquirido por una sociedad constructora que procedió a su derribo. Mejor suerte corrió el templo que, al no ser vendido, continuó abierto al culto. En 1877 se convirtió en parroquia, al unírsele la iglesia de San Nicolás y San Eulogio de la Ajerquía. Tampoco serían destruidas las alas oriental y meridional del claustro principal, por encontrarse adosadas al templo, quedando así insertas en el espacio urbano parte de las dependencias del antiguo cenobio. Sobre el terreno que ocuparan el edificio monástico y su huerto se trazaron varias calles. Estas vías dieron vida a un nuevo barrio interior, promovido por iniciativa particular, que en 1897 estaba ya prácticamente formado.

El Ex-convento de San Agustín fue vendido también a un particular, alzándose sobre su antiguo solar un nuevo barrio. Tan sólo subsistiría la iglesia, que llegaría a nuestros días en un estado bastante lamentable. ${ }^{40}$ El que fuese Convento de la Victoria pasó igualmente a manos particulares, convirtiéndose en almacén de maderas. En 1865 fue comprado por el Ayuntamiento, que procedió a su derribo para ampliar el espacio destinado, anualmente, a la Feria de Ntra. Sra. de la Salud, pasando su huerto a utilizarse como vivero. La demolición de este cenobio abriría en Córdoba una gran disputa entre «antiguos» y «modernos»; es decir, entre los defensores de la historia y de su legado artístico, y los paladines de la modernidad. Tal polémica volvería a repetirse, en más de una ocasión, ante la oleada de derribos importantes que se acometieron a partir de entonces. ${ }^{41}$

Los procesos desamortizadores continuarían su andadura durante el siglo XIX. Respecto al tema que nos ocupa, hemos de centrarnos en la Revolución de 1868. La llamada «Gloriosa» traería consigo el afán demoledor -al que antes nos referíamos-, afectando de lleno a varios cenobios femeninos. A este respecto, cabe recordar cómo seis años antes, Isabel II otorgaba veintiocho mil reales de limosna a los trece conventos de religiosas de la ciudad y al convento de la villa de Palma del Río, a razón de dos mil reales cada uno. ${ }^{42}$ Esto justifica la mala situación económica en la que se hallaban las comunidades femeninas.

Las consecuencias urbanísticas derivadas de la Revolución de 1868, serían especialmente significativas en dos cenobios cistercienses: el de la Purísima Concepción de Ntra. Sra. y el de Santa María de las Dueñas, uniéndose ambas comunidades a las religiosas del Monasterio de la Encarnación. ${ }^{43}$

\footnotetext{
${ }^{40}$ Sin embargo, tras un largo proceso de restauración, el antiguo templo agustino fue abierto nuevamente al culto en el año 2009.

${ }^{41}$ Vid. Ramírez de Arellano y Gutiérrez. 1998: 318. Ramírez y de las Casas-Deza, L. M. 1976: 199. Martín López, C. 1990: 94-109. Palencia Cerezo, J. M. 1995: 89-91.

${ }^{42}$ A.G.O.C. (Archivo General del Obispado de Córdoba). Secretaría: Órdenes y Congregaciones Religiosas Femeninas, Sig. 6948/04.

${ }^{43}$ Cfr. Martín López, C. 1990: 361-369 y 441-445.
}

Hispania Sacra, LXIV

129, enero-junio 2012, 29-66, ISSN: 0018-215-X, doi: 10.3989/hs.2012.002 
El edificio del Monasterio de la Concepción de Ntra. Sra. pasó a su antiguo patrono, el duque de Fernán Núñez, quien inició su derribo en 1887. Su amplio solar quedó subdividido en varios solares en los que se erigieron casas. En el centro de este gran espacio se abrió una calle, que fue cedida por el citado noble en beneficio público, siendo urbanizada por el Ayuntamiento. Vemos, pues, cómo en este caso el proceso desamortizador permitió mejorar la comunicación de la trama urbana, favoreciendo además el negocio inmobiliario en una céntrica zona de la ciudad.

Por su parte, el Monasterio de Santa María de las Dueñas quedó convertido en cuartel de la Guardia Civil. Ante el estado de ruina que presentaba parte del edificio, en 1869 fue derribado el sector afectado, abriéndose en su lugar una plaza ajardinada que llevaría el nombre de las Dueñas. Este nuevo espacio permitió descongestionar una zona urbana de estrechas calles, favoreciendo además la alineación de las vías inmediatas. La parte del antiguo cenobio que permaneció en pie fue adquirida por un particular, que optó por derribarla alzando en su solar una nueva casa. De este modo, no llegaría a ampliarse la plaza como era el deseo de la Corporación Municipal.

A este respecto, cabe recordar la publicación en el Boletín Oficial de la Provincia de Córdoba, de la subasta del antiguo templo de las Dueñas, a celebrar el 17 de junio del mismo año. ${ }^{44}$ Este hecho levantaría la protesta de las autoridades eclesiásticas, que no pudieron frenar tal acuerdo. Así lo expresaba el Vicario Capitular de la Diócesis de Córdoba, el mismo día en que se publicaba la subasta, en un oficio dirigido al Sr. Comisionado General de ventas de propiedades y derechos del Estado:

«... No hallo medio que valor tenga no ya para justificar, porque esto no puede ser peso ni siquiera para explicar este hecho, que contraviene las leyes generales de desamortización por las que se excluyen terminantemente los templos, sin que sirva de excusa el no estar dedicados al culto, pues esto depende de circunstancias fáciles de comprender...». ${ }^{45}$

Distinta fue la suerte del resto de las clausuras suprimidas en 1868. El antiguo Convento de Jesús Crucificado quedó convertido en Asilo del Buen Pastor. Desde 1886 se efectuaron obras en el inmueble, con el fin de adaptarlo a su nuevo cometido. Por su parte, el que fuese el primer cenobio de la ciudad, el Monasterio de Santa Clara, ejercería varias funciones que no hicieron sino agravar su deterioro. Primeramente, se pensó en destinarlo a cuartel, pero dado el mal estado en el que se encontraba el edificio se decidió su derribo y la apertura en su solar de una plaza pública. Esta última resolución no llegó a materializarse,

${ }^{44}$ A.G.O.C. Secretaría: Órdenes y Congregaciones Religiosas Femeninas. Sig. 6950/01. Boletín Oficial del Estado, núm. 274, Jueves 8 de Mayo de 1875.

${ }^{45}$ Ibídem. Carta del Vicario Capitular de la Diócesis de Córdoba, al Sr. Comisionado General de ventas de propiedades y derechos del Estado, f. 1 vto. 
sirviendo en 1870 para alojar a las Compañías de Infantería. Cuando el inmueble dejó de ser útil al ejército, se determinó asignarlo para clases de Bellas Artes, propuesta que tampoco llegaría a efectuarse. La Hacienda Nacional terminaría vendiendo el antiguo conjunto monástico a Mariano Muñoz Vázquez, quien lo dividió en varios compartimentos. Posteriormente, sería ocupado por un colegio hasta 1878 , quedando en lo sucesivo sumido en el abandono. ${ }^{46}$

Un caso diferente, en el proceso de desaparición de clausuras femeninas, lo constituye el Convento de la Encarnación Agustina, suprimido en 1804 por la disminución del número de religiosas. La escasa comunidad existente entonces fue trasladada al Convento de las Nieves. Convertido primeramente el antiguo edificio cenobial en hospicio, a mediados de siglo se establecía en el mismo la Escuela Nacional de Veterinaria y el Cuartel de la Guardia Civil, siendo este último trasladado después al Ex-monasterio de Santa María de las Dueñas. ${ }^{47}$

Finalmente, hemos de referirnos a las clausuras femeninas que no fueron suprimidas. Tal es el caso del Convento de Santa Isabel de los Ángeles, si bien sus religiosas padecieron las secuelas desamortizadoras. En 1875 fue expropiada parte de la huerta del cenobio para ensanchar la calle Isabel Losa ${ }^{48}$ Mejor suerte corrieron las dominicas del Corpus Christi, cuyo convento no se vio afectado por ninguna desamortización. Sin embargo, no faltaron ocasiones y peticiones solicitando que sí lo fuera con el fin de demolerlo -a la vez que los de Santa Marta y Santa Clara- para crear nuevos espacios libres, con arboleda, que permitieran descongestionar y ventilar la densa trama urbana cordobesa. ${ }^{49}$ Por fortuna, el Monasterio de Santa Marta se libraría también de tales medidas urbanísticas. Asimismo, tampoco serían suprimidos los cenobios de la Anunciación de Ntra. Sra., Santa Ana, Santa Cruz, Santa María de Gracia, San Rafael y Ntra. Sra. de la Concepción (El Cister).

Todo el proceso comentado queda ilustrado en la Figura 2, en la que se indican los cenobios masculinos exclaustrados y las clausuras femeninas suprimidas. Tan sólo prevalecieron -como hemos indicado- unos cuantos claustros de religiosas, menos de la mitad de los que existieron en la ciudad.

\section{A MODO DE CONCLUSIÓN}

Lo expuesto hasta aquí permite deducir cómo desde la etapa bajomedieval, y a lo largo de las centurias modernas, se aprecia el gran protagonismo físico y espiritual de los cenobios de Córdoba, hasta el punto de dominar, en gran me-

\footnotetext{
${ }^{46}$ Vid. Palencia Cerezo, J. M. 1995: 83-85.

${ }^{47}$ Cfr. Ramírez de Arellano y Gutiérrez, T. 1998: 201-202. Ramírez y de las Casas-Deza, L. M. 1976: 221.

${ }^{48}$ Seguimos a Orti Belmonte, M. A. 1980: 469-470.

${ }^{49}$ García Verdugo, F. R.1997: 97. 
dida, el espacio urbano de la ciudad. Tal imagen empezaría a quebrarse a fines del Setecientos, con la expulsión de los jesuitas, hecho que supuso un proemio a los procesos de exclaustración que fueron sucediéndose en la capital cordobesa durante el siglo XIX. La desamortización eclesiástica traería consigo la desaparición de numerosos cenobios (siendo sus edificios derribados o adaptados a otros fines), perdiendo espacios e inmuebles las comunidades religiosas que sobreviven. Con el tiempo, algunas órdenes volverían a recuperar sus edificios, si bien este hecho no impediría algo que era ya evidente e imparable: la laicización de la urbe, tendencia que define a la Córdoba del siglo XIX y que seguiría vigente en lo sucesivo.

\section{Cuadros 1 y 2 \\ Fundaciones cenobiales efectuadas en Córdoba durante la etapa bajomedieval}

\begin{tabular}{|l|l|}
\hline \multicolumn{1}{|c|}{ Fundaciones masculinas } & \multicolumn{1}{c|}{ Ubicación } \\
\hline 1. Monasterio de San Pablo. & Collación de San Andrés (la Ajerquía). \\
\hline 2. Monasterio de San Pedro el Real. & Collación de San Nicolás de la Ajerquía. \\
\hline 3. Monasterio de la Santísima Trinidad. & Collación de Omnium Sanctorum (la Villa). \\
\hline 4. Monasterio de San Agustín. & Collación de Santa Marina (la Ajerquía). \\
\hline 5. Convento de Ntra. Sra. de la Merced. & $\begin{array}{l}\text { A extramuros, en el ámbito septentrional de la } \\
\text { ciudad. }\end{array}$ \\
\hline $\begin{array}{l}\text { 6. Convento de los Santos Mártires. } \\
\text { 7. Monasterio de San Jerónimo de Valparaí- } \\
\text { so. }\end{array}$ & $\begin{array}{l}\text { A extramuros, dentro de la demarcación de la } \\
\text { collación de Santiago (la Ajerquía). }\end{array}$ \\
\hline Azahara, ciudad palatina de la época califal. \\
\hline $\begin{array}{l}\text { 9. Convento de San Francisco de la Arruzafa. } \\
\text { (San Álvaro). }\end{array}$ & Al pie de la Sierra de Córdoba. \\
\hline $\begin{array}{l}\text { 10. Convento de Ntra. Sra. de los Remedios y y } \\
\text { San Rafael (Convento Madre de Dios). }\end{array}$ & $\begin{array}{l}\text { Junto al arroyo de Pedroche, al noreste de la } \\
\text { ciudad. }\end{array}$ \\
\hline
\end{tabular}

\begin{tabular}{|l|l|}
\hline \multicolumn{1}{|c|}{ Fundaciones femeninas } & \multicolumn{1}{c|}{ Ubicación } \\
\hline 1. Monasterio de Santa Clara. & Collación de Santa María (la Villa). \\
\hline 2. Monasterio de Santa María de las Dueñas. & Collación de San Salvador (la Villa). \\
\hline 3. Convento de Santa Inés. & Collación de la Magdalena (la Ajerquía). \\
\hline 4. Convento de Santa Cruz. & Collación de San Pedro (la Ajerquía). \\
\hline 5. Convento de Santa Isabel de los Ángeles. & Collación de Santa Marina (la Ajerquía). \\
\hline 6. Monasterio de Santa Marta. & Collación de San Andrés (la Ajerquía). \\
\hline 7. Convento de Santa María de Gracia. & Collación de San Lorenzo (la Ajerquía). \\
\hline 8. Convento de Regina Coeli. & Collación de San Pedro (la Ajerquía). \\
\hline
\end{tabular}




\section{Cuadros 3 y 4}

\section{Fundaciones cenobiales efectuadas en Córdoba durante la etapa moderna}

\begin{tabular}{|l|l|}
\hline \multicolumn{1}{|c|}{ Fundaciones masculinas } & \multicolumn{1}{|c|}{ Ubicación } \\
\hline $\begin{array}{l}\text { 1. Convento de Ntra. Sra. de las Huertas } \\
\text { (Convento de la Victoria). }\end{array}$ & $\begin{array}{l}\text { A extramuros, en el extremo occidental de la } \\
\text { ciudad. }\end{array}$ \\
\hline 2. Convento de Ntra. Sra. de la Cabeza. & Collación de la Magdalena (la Ajerquía). \\
\hline $\begin{array}{l}\text { 3. Casa de la Compañía de Jesús (Colegio de } \\
\text { Santa Catalina). }\end{array}$ & $\begin{array}{l}\text { Collación de Santo Domingo de Silos (la Vi- } \\
\text { lla). }\end{array}$ \\
\hline $\begin{array}{l}\text { 4. Convento de San José (San Cayetano). } \\
\text { A extramuros, en el ámbito septentrional de la } \\
\text { ciudad. }\end{array}$ \\
\hline $\begin{array}{l}\text { 6. Convento de San Basilio. } \\
\text { Pedro el Real. }\end{array}$ & Collación de San Bartolomé (la Villa). \\
\hline $\begin{array}{l}\text { 7. Convento de San Juan Bautista (el Desier- } \\
\text { to) }\end{array}$ & $\begin{array}{l}\text { A extramuros, en el extremo oriental de la ciu- } \\
\text { dad. } \\
\text { Trassierra. }\end{array}$ \\
\hline 8. Convento de Ntra. Sra. de Gracia. & Collación de San Lorenzo (la Ajerquía). \\
\hline 9. Convento del Santo Ángel. & Collación de San Salvador (la Villa). \\
\hline 10. Convento de San Pedro de Alcántara. & Collación de Santa María (la Villa). \\
\hline 11. Oratorio de San Felipe Neri. & Collación de Omnium Sanctorum (la Villa). \\
\hline
\end{tabular}

\begin{tabular}{|l|l|}
\hline \multicolumn{1}{|c|}{ Fundaciones femeninas } & \multicolumn{1}{c|}{ Ubicación } \\
\hline $\begin{array}{l}\text { 1. Monasterio de la Anunciación de Ntra. } \\
\text { Sra. (Monasterio de la Encarnación) }\end{array}$ & Collación de Santa María (la Villa). \\
\hline 2. Monasterio de la Concepción. & Collación de San Nicolás de la Villa. \\
\hline 3. Convento de Santa María de las Nieves. & $\begin{array}{l}\text { Fundado en la collación de San Lorenzo (Ajer- } \\
\text { quía) y trasladado poco después a la collación } \\
\text { de San Salvador (la Villa). }\end{array}$ \\
\hline 4. Convento del Espíritu Santo. & Collación de San Salvador (la Villa). \\
\hline 5. Convento de Jesús Crucificado. & Collación de Santa María (la Villa). \\
\hline 6. Convento de Jesús y María. & $\begin{array}{l}\text { Collación de Santo Domingo de Silos (la Vi- } \\
\text { lla). }\end{array}$ \\
\hline 7. Convento de Santa Ana. & Collación de Santa María (la Villa). \\
\hline 8. Convento del Corpus Christi. & Collación de Santa María (la Villa). \\
\hline 9. Convento de la Encarnación Agustina. & Collación de San Pedro (la Ajerquía). \\
\hline 10. Convento de San Martín & Collación de San Nicolás de la Villa. \\
\hline $\begin{array}{l}\text { 11. Convento de San Rafael. (Convento de } \\
\text { Capuchinas). }\end{array}$ & Collación de San Salvador (la Villa). \\
\hline $\begin{array}{l}\text { 12. Convento de Ntra. Sra. de la Concepción. } \\
\text { (El Cister). }\end{array}$ & Collación de San Salvador (la Villa). \\
\hline
\end{tabular}


Figura 1

Panorama conventual de Córdoba a mediados del siglo XVIII

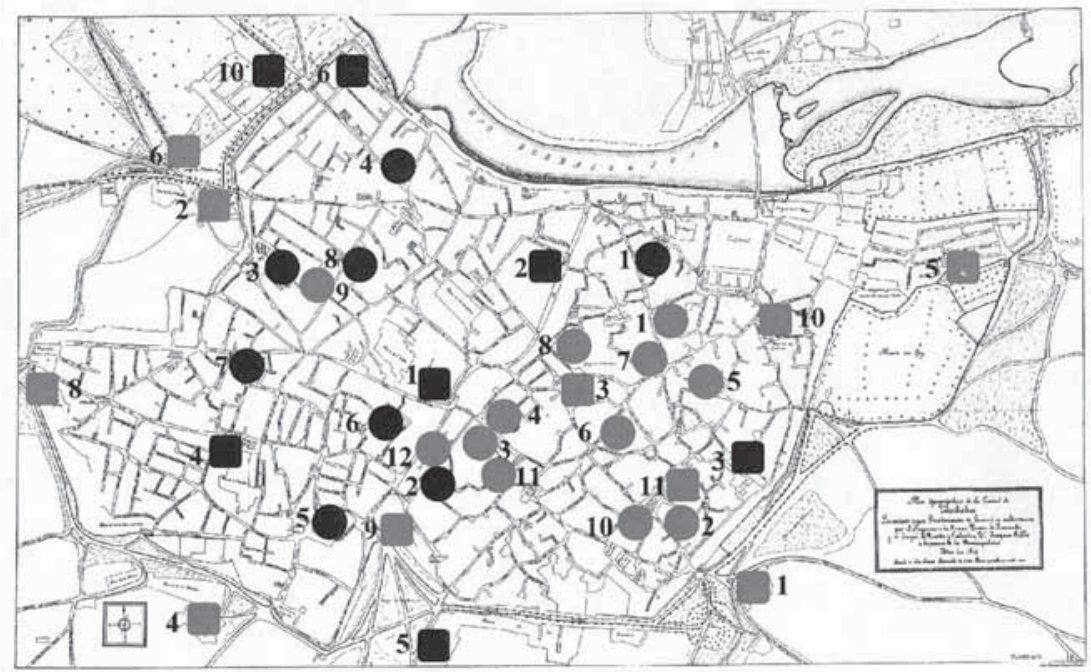

Seguimos la numeración de los cuadros anteriores.

Fundaciones masculinas de la etapa bajomedieval.

Fuera del plano: 7. Monasteriode Valparaíso. 8. Convento de San

Francisco de la Arruzafa. 9. Convento de Santo Domingo de Scalacoeli.

Fundaciones femeninas de la etapa bajomedieval.

Fundaciones masculinas de la época moderna.

Fuera del plano: 7. Convento de San Juan Bautista (el Desierto).

Fundaciones femeninas de la época moderna. 


\section{Figura 2}

\section{Panorama conventual a finales del siglo XVIII}

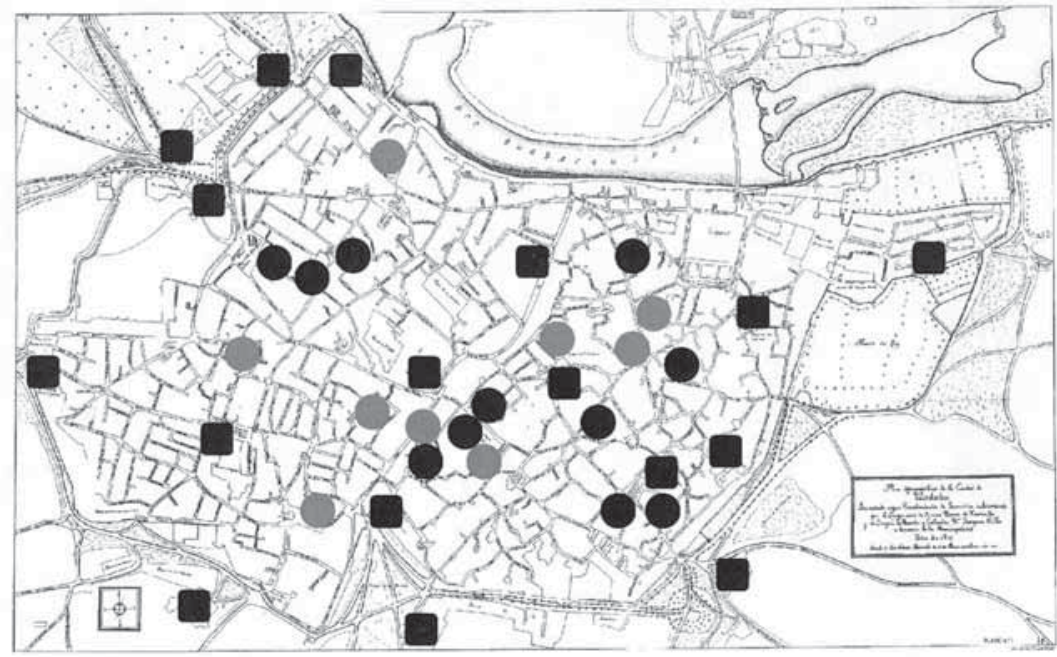

Cenobios masculinos exclaustrados. Fuera del Plano, también fueron exclaustrados el Monasterio de Valparaíso, el Convento de San Francisco de la Arruzafa y el Convento de Santo Domingo de Scalacoeli.

- Cenobios femeninos suprimidos.

Cenobios femeninos no suprimidos.

\section{BIBLIOGRAFÍA}

Anguita González, J. 1984. La desamortización eclesiástica en la ciudad de Córdoba (1836-1845). Córdoba: Albolafia.

Aranda Doncel, J. 2007. «Las exclaustraciones de las órdenes religiosas en la Córdoba del primer tercio del siglo XIX: el convento de los terciarios regulares de San Francisco», en F. J. Campos y Fdez. de Sevilla (dir.), La desamortización: El expolio del patrimonio artístico y cultural de la Iglesia en España. Actas del Simposium: 259-278. San Lorenzo del Escorial (Madrid): R.C.U. Escorial-M ${ }^{a}$ Cristina, Servicio de Publicaciones.

Atienza López, A. 2008. Tiempos de conventos. Una historia social de las fundaciones en la España Moderna. Madrid: Marcial Pons. Logroño: Universidad de Logroño. 
Atienza López, A. 2009. «Nuevas consideraciones sobre la geografía y la presencia conventual en la España Moderna. Otras facetas más allá de la concentración urbana». Hispania Sacra 123: 51-75.

Barrios Rozúa, J. M. 1998. Reforma urbana y destrucción del patrimonio histórico en Granada. Ciudad y Desamortización. Granada: Universidad de Granada. Junta de Andalucía.

Barrios Rozúa, J. M. 2007. «Los conventos andaluces frente a la desamortización de las Cortes de Cádiz y el anticlericalismo», en F. J. Campos y Fdez. de Sevilla (dir.), $L a$ desamortización: El expolio del patrimonio artístico y cultural de la Iglesia en España. Actas del Simposium: 119-138. San Lorenzo del Escorial (Madrid): Escorial$\mathrm{M}^{\mathrm{a}}$ Cristina, Servicio de Publicaciones.

Castellano Cuesta, M. T. 1988. La Iglesia de San Francisco y San Eulogio de la Ajerquía de Córdoba. Córdoba: Monte de Piedad y Caja de Ahorros de Córdoba.

Castro Castillo, M. R. 1996. «La urbanización de la huerta de San Francisco en Córdoba», en M. Peláez del Rosal (dir. y ed.), El franciscanismo en Andalucía. Conferencias del II Curso de Verano San Francisco en la historia y en el arte andaluz: 45-49. Córdoba: Caja Madrid, Obra Social.

Cerrato Mateos, F. 2006. El Cister de Córdoba. Historia de una clausura. Córdoba: Universidad de Córdoba.

Cerrato Mateos, F. 2011. «El monasterio de la Encarnación de Córdoba. Universalidad y originalidad de una fundación cisterciense», en F. J. Campos y Fdez. de Sevilla (coord.), La clausura femenina en el Mundo Hispánico: Una fidelidad secular. Actas del Simposium II: 725-739. San Lorenzo del Escorial (Madrid): R.C.U. Escorial-Ma Cristina, Servicio de Publicaciones.

Cosano Moyano, F. 1999. Iconografía de Córdoba. Siglos XIII-XIX. Catalogación de imágenes urbanas, heráldicas, hagiográficas y de poblaciones del antiguo reino de Córdoba. Córdoba: Caja de Ahorros y Monte de Piedad de Córdoba, Obra Social y Cultural.

Domínguez Ortiz, A. 1988. Carlos III y la España de la Ilustración. Madrid: Alianza.

Escobar Camacho, J. M. 1985. La vida urbana cordobesa: El Potro y su entorno en la Baja Edad Media. Córdoba: Caja Provincial de Ahorros de Córdoba, Obra Cultural.

Escobar Camacho, J. M. 1989. Córdoba en la Baja Edad Media. (Evolución urbana de la ciudad). Córdoba: Caja Provincial de Ahorros de Córdoba.

Escobar Camacho, J. M. 1999. «La ciudad de Córdoba a fines del siglo XVI: su evolución urbana», en R. Vázquez Lesmes y M. Ventura Gracia (coords.), Córdoba en tiempos de Felipe II. Actas de las Jornadas de la Real Academia de Córdoba: 173-185. Córdoba: Caja de Ahorros y Monte de Piedad de Córdoba, Obra Social y Cultural.

Escribano Castilla, A. 1982. «Fundaciones franciscanas en la Córdoba bajomedieval», en Andalucía Medieval. Actas I Coloquio Historia de Andalucía: 331-351. Córdoba: Monte de Piedad y Caja de Ahorros de Córdoba.

Fraga Iribarne, M. L. 1993. Conventos femeninos desaparecidos. Arquitectura religiosa perdida durante el siglo XIX en Sevilla. Sevilla: Guadalquivir.

García Verdugo, F. R. 1992. Córdoba, Burguesía y Urbanismo. Producción y Propiedad del Suelo Urbano: El Sector de Gran Capitán, 1859-1936. Córdoba: Ayuntamiento de Córdoba, Gerencia de Urbanismo. 
García Verdugo, F. R. 1997. «El entorno urbano en los siglos XIX y XX», en A. Villar Movellán (dir.), El Convento de Dominicas del Corpus Christi de Córdoba (16091992): 79-120. Córdoba: CajaSur.

Gómez Navarro, S. 2005. «Por esos caminos de Dios: Asentamiento y expansión del monacato femenino en la Córdoba Moderna», en M. I. Viforcos Marinas y M. D. Campos Sánchez (coords.), Fundadores, fundaciones y espacios de vida conventual. Nuevas aportaciones al monacato femenino. III Congreso Internacional sobre el Monacato Femenino en España, Portugal y América: 191-212. León: Universidad de León.

Gracia Boix, R. 1973. El Real Monasterio de San Jerónimo de Valparaíso en Córdoba. Córdoba: Real Academia de Córdoba de Ciencias, Bellas Letras y Nobles Artes.

Gutiérrez de los Ríos y Pareja-Obregón, M. 1909. Fundaciones monásticas en la Sierra de Córdoba. Córdoba: Diario Córdoba.

Herrera Mesa, P. P. 2004. «El Real Convento de Santa Inés de Córdoba: fundación, patrimonio y desaparición», en F. J. Campos y Fdez. de Sevilla (dir.), La clausura femenina en España. Actas del Simposium II: 911-938. San Lorenzo del Escorial (Madrid): R.C.U. Escorial-Ma Cristina, Servicio de Publicaciones.

Jordano Barbudo, M. A. 1996. Arquitectura medieval cristiana en Córdoba (desde la reconquista al inicio del Renacimiento). Córdoba: Universidad de Córdoba, Servicio de Publicaciones.

Jordano Barbudo, M. A. 1999. «Conventos de jerónimas en antiguos palacios mudéjares: el ejemplo de Santa Marta en Córdoba», en F. J. Campos y Fdez. de Sevilla (dir.), La Orden de San Jerónimo y sus Monasterios. Espiritualidad, historia, arte, economía y cultura de una Orden religiosa ibérica. Actas del Simposium I: 359379. San Lorenzo del Escorial (Madrid): R.C.U. Escorial-M ${ }^{\mathrm{a}}$ Cristina, Servicio de Publicaciones.

Jordano Barbudo, M. A. 2002. El Mudéjar en Córdoba. Córdoba: Diputación Provincial de Córdoba.

Marfil Ruiz, P. 1996. «La iglesia paleocristiana de Santa Catalina en el Convento de Santa Clara de Córdoba». Caetaria 1: 33-43.

Martí Gilabert, F. 2003. La desamortización española. Madrid: Rialp.

Martín López, C. 1990. Córdoba en el siglo XIX. Modernización de una trama urbana. Córdoba: Ayuntamiento de Córdoba, Gerencia de Urbanismo.

Moreno Cuadro, F. y Palencia Cerezo, J. M. 1989. San Juan de la Cruz y Córdoba. El convento de Santa Ana. Catálogo de la exposición conmemorativa del Cuarto Centenario de la Fundación del Convento de Carmelitas Descalzas de Santa Ana de Córdoba, 1589-1989. Córdoba: Monte de Piedad y Caja de Ahorros de Córdoba.

Nieto Cumplido, M., Padilla González, J. y Escobar Camacho, J. M. 1984. «Vida y presencia de la mujer en la Córdoba del siglo XIII», en C. Segura Graíño (ed.), Las mujeres en las ciudades medievales. Actas de las Terceras Jornadas de Investigación Interdisciplinaria: 125-141. Madrid: Universidad Autónoma de Madrid, Servicio de Publicaciones.

Nieto Cumplido, J. M. 2003. «La Iglesia de Córdoba», en J. M. Nieto Cumplido (coord.), Iglesias de Córdoba y Jaén. Historia de las Diócesis Españolas, Vol. 8: 5-191. Madrid: Biblioteca de Autores Cristianos. Córdoba: CajaSur. 
Orti Belmonte, M. A. 1980. Córdoba monumental, artística e histórica. Córdoba: Diputación Provincial de Córdoba. (Segunda edición).

Orti Belmonte, M. A.1989. «El Convento de Santa Marta», Vida y Comercio 48: s.p.

Palencia Cerezo, J. M. 1995. Setenta años de intervención en el patrimonio históricoartístico cordobés (1835-1905). Córdoba: Caja de Ahorros y Monte de Piedad de Córdoba, Obra Social y Cultural.

Porres Alonso, B. 1998. Nuestra Señora de Gracia. Un convento cordobés del XVII: 2337 y 39-68. Córdoba: Caja de Ahorros y Monte de Piedad de Córdoba, Obra Social y Cultural.

Porres Alonso, B. 2007. La Trinidad de Córdoba. Convento y parroquia (1236-1998). Córdoba: Secretariado Trinitario.

Puchol Caballero, M. D. 1992. Urbanismo del Renacimiento en la ciudad de Córdoba. Córdoba: Diputación Provincial de Córdoba.

Ramírez de Arellano y Díaz de Morales, R. 1983. Inventario monumental y artístico de la provincia de Córdoba. (Con notas de J. Valverde Madrid).

Córdoba: Monte de Piedad y Caja de Ahorros de Córdoba.

Ramírez de Arellano y Gutiérrez, T. 1998. Paseos por Córdoba, o sean Apuntes para su Historia. (Prólogo de M. Salcedo Hierro). Córdoba: Librería Luque. León: Everest. (Octava edición).

Ramírez y de las Casas-Deza, L. M. 1976. Indicador cordobés. Manual histórico topográfico de la ciudad de Córdoba. León: Everest. (Edición realizada partiendo de la cuarta edición hecha en Córdoba en 1867).

Raya Raya, M. A. 2011. «El monasterio cisterciense de Nuestra Señora de la Encarnación de Córdoba: estudio artístico», en F. J. Campos y Fdez. de Sevilla (coord.), La clausura femenina en el Mundo Hispánico: Una fidelidad secular. Actas del Simposium II: 741-757. San Lorenzo del Escorial (Madrid): R.C.U. Escorial-M ${ }^{a}$ Cristina, Servicio de Publicaciones.

Rodríguez G. de Ceballos, A. 2002. La arquitectura de los Jesuitas. Madrid: Edilupa.

Rodríguez G. de Ceballos, A. 2004. «Arquitectura y arquitectos en la provincia jesuítica de Andalucía», en F. García Gutiérrez (coord.), El arte de la Compañía de Jesús en Andalucía (1554-2004): 57-134. Córdoba: Caja de Ahorros y Monte de Piedad de Córdoba, Obra Social y Cultural.

Rodríguez Marín, F. J. 2000. Málaga Conventual. Estudio Histórico, Artístico y Urbanístico de los Conventos Malagueños. Málaga: CajaSur, Obra Social y Cultural. Arguval.

Serrano Ovín, V. 1975. «La iglesia del Real Convento de San Pablo. Córdoba». Boletín de la Real Academia de Córdoba 95: 76-130.

Sobrón Elguea, M. C. 2004. Impacto de la desamortización de Mendizábal en el paisaje urbano de Zaragoza. Zaragoza: Institución Fernando el Católico.

Taylor, R. 1986. «San Felipe Neri», en M. Peláez del Rosal y C. Pérez Almenara (eds.), El Barroco en Andalucía. III Curso de Verano: 100-101. Córdoba: Universidad de Córdoba.

Vázquez Lesmes, J. R. 1978. «Monasterio y colegiata de San Hipólito de Córdoba (1343-1399)», en Andalucía Medieval. Actas I Congreso de Historia de Andalucía, Vol. 2: 147-161. Córdoba: Monte de Piedad y Caja de Ahorros de Córdoba. 
Vázquez Lesmes, R. 2007. «Extrañamiento de los jesuitas y desamortización de sus temporalidades en Córdoba (1767-1769)», en F. J. Campos y Fdez. de Sevilla (dir.), La desamortización: El expolio del patrimonio artístico y cultural de la Iglesia en España.

Actas del Simposium: 241-258. San Lorenzo del Escorial (Madrid): Escorial-Ma Cristina, Servicio de Publicaciones.

Villar Movellán, A. (dir.). 1997. El Convento de Dominicas del Corpus Christi de Córdoba (1609-1992). Córdoba: CajaSur. 